\title{
Machine Learning Prediction of Food Processing
}

\author{
Giulia Menichetti ${ }^{1,2}, \quad$ Babak Ravandi $^{1}, \quad$ Dariush Mozaffarian ${ }^{4}$, \\ Albert-László Barabási ${ }^{1,2,3 \dagger}$ \\ ${ }^{1}$ Network Science Institute and Department of Physics, Northeastern University, Boston, USA \\ ${ }^{2}$ Department of Medicine, Brigham and Women's Hospital, Harvard Medical School, \\ Boston, USA \\ ${ }^{3}$ Department of Network and Data Science, Central European University, Budapest, Hungary \\ ${ }^{4}$ Tufts Friedman School of Nutrition Science \& Policy, Boston, USA
}

Despite the accumulating evidence that increased consumption of ultra-processed food has adverse health implications, it remains difficult to decide what constitutes processed food. Indeed, the current processing-based classification of food has limited coverage and does not differentiate between degrees of processing, hindering consumer choices and slowing research on the health implications of processed food. Here we introduce a machine learning algorithm that accurately predicts the degree of processing for any food, indicating that over $73 \%$ of the U.S. food supply is ultra-processed. We show that the increased reliance of an individual's diet on ultra-processed food correlates with higher risk of metabolic syndrome, diabetes, angina, elevated blood pressure and biological age, and reduces the bio-availability of vitamins. Finally, we find that replacing foods with less processed alternatives can significantly reduce the health implications of ultra-processed food, suggesting that access to information on the degree of processing, currently unavailable to consumers, could improve population health. 
medRxiv preprint doi: https://doi.org/10.1101/2021.05.22.21257615; this version posted May 25 , 2021 . The copyright holder for this preprint (which was not certified by peer review) is the author/funder, who has granted medRxiv a license to display the preprint in perpetuity. It is made available under a CC-BY-NC-ND 4.0 International license .

\section{Introduction}

Unhealthy diet is a major risk factor for multiple non-communicable diseases, from obesity and type 2 diabetes to coronary heart disease (CHD) and cancer, together accounting for $70 \%$ of mortality and $58 \%$ of morbidity worldwide $[1,2]$. Traditionally, consumers rely on food categorybased dietary recommendations like the Food Pyramid (1992 [3]) or MyPlate (2011 [4]), which define the mix of fruits, vegetables, grains, dairy and protein-based foods that constitute a healthy diet. In recent years, however, an increasing number of research studies and dietary guidelines have identified the important role and separate health effects of food processing [5-9]. Observational studies, meta-analysis, and controlled metabolic studies suggest that dietary patters relying on unprocessed foods are more protective than the processing-heavy Western diet against disease risk [10].

A landmark, widely used classification system for food processing is the NOVA system [11], which categorizes individual foods into four broad categories: unprocessed or minimally processed (NOVA 1), like fresh, dry or frozen fruits or vegetables, grains, legumes, meat, fish and milk; culinary ingredients (NOVA 2), like table sugars, oils, fats and salt; processed foods (NOVA 3), like canned food, simple bread and cheese; and ultra-processed products (NOVA 4), everything else including packaged breads, cookies, sweetened breakfast cereals, margarines, sauces and spreads, carbonated drinks, hot dogs, hamburgers and pizzas. Epidemiological studies have documented significant associations between greater consumption of the highest NOVA category of processing (NOVA 4, ultra-processed food) and diseases onset [12-18], including links to obesity [19], CHD [17,20], diabetes mellitus [21], cancer [16], and depression [15]. A randomized controlled metabolic trial has also confirmed short-term adverse effects of ultra-processed foods, compared with unprocessed foods, on caloric intake and weight gain [18].

Despite its successes, NOVA classification of food items is laborious and incomplete, limiting research into the impact of processed food. First, as the current categorization relies on expertise-based manual evaluation of each food, it covers only $35 \%$ of the foods catalogued by U.S. Department of Agriculture (USDA) (SI Section 1). Second, the classification of composite recipes, products, and mixed meals including different types of processed items - a large proportion of the food supply - is not straightforward. Hence, current approaches have classified all foods with at least one ultra-processed ingredient as ultra-processed [16,22], reducing the discrimination of such foods in relation to health outcomes [23,24]. Third, all the observed risk for the NOVA classification is in the NOVA 4 class, representing a large and heterogeneous category of ultra-processed food that does not allow investigation of the health implications of different gradations of processing. Indeed, according to NOVA, many nations derive up to $60 \%$ 
medRxiv preprint doi: https://doi.org/10.1101/2021.05.22.21257615; this version posted May 25 , 2021 . The copyright holder for this preprint (which was not certified by peer review) is the author/funder, who has granted medRxiv a license to display the preprint in perpetuity.

It is made available under a CC-BY-NC-ND 4.0 International license .

or more of their average caloric intake from ultra-processed foods [24-26], and within this class each food item is considered identical. These challenges limits both scientific research and practical consumer guidance on the health effects of differing degrees of processing and consumer choices, and also reduce industry incentives to reformulate foods to be less processed.

To overcome these limitations, here we introduce FoodProX, a machine learning classifier trained to predict the degree of processing of any food. Importantly, FoodProX allows us to define a continuous index that captures the degree of processing of any food, and can help quantify the overall diet quality of individuals, unveiling statistical correlations between the degree of processing characterizing individual diets and multiple disease phenotypes.

\section{Results}

The time consuming manual procedure behind NOVA, relying on the ingredients of food, has allowed a straightforward labeling to 2,484 foods reported in the National Health and Nutrition Examination Survey (NHANES) 2009-2010, representing 34.25\% of items consumed by a representative sample of the U.S. population [13] (SI Section 1). The remaining foods are either not classified, or require further decomposition into their differing food ingredients, often not reported by the manufacturers. In contrast, the basic nutrient profile of foods and beverages is always disclosed, mandated by law in most countries. For example, the USDA Standard Reference database (USDA SR Legacy), catalogues the nutrient profile of 7,793 foods with resolutions ranging from 8 to 138 nutrients (Figure S1) [27], and USDA FNDDS reports between 65 to 102 nutrients for all foods consumed by NHANES participants [28, 29].

Our work relies on the hypothesis that the nutrient profiles of unprocessed or minimally processed foods are generally constrained within common physiologic ranges [30]. The nutrient profile can be widely altered by the physical, biological and chemical processes involved in food preparation and conservation, thus correlating with the degree of processing undertaken. Indeed, among the nutrients reported in raw onion, $3 / 4$ change their concentration in excess of $10 \%$ in the fried and battered version of the product, and more than half by 10-fold (Figure 1B). We lack however, a single nutrient "biomarker" that accurately tracks the degree of processing; instead we observe changes in the concentration of multiple nutrients, whose combinations jointly correlate with processing. This complexity advocates for the use of machine learning, designed to capture the combinatorial explosion of nutrient alterations. 
medRxiv preprint doi: https://doi.org/10.1101/2021.05.22.21257615; this version posted May 25, 2021. The copyright holder for this preprint (which was not certified by peer review) is the author/funder, who has granted medRxiv a license to display the preprint in perpetuity.

It is made available under a CC-BY-NC-ND 4.0 International license.

\section{FoodProX Algorithm}

We leveraged the nutrient concentrations provided in FNDDS 2009-2010 for the foods handclassified by NOVA [13] to train FoodProX, a multi-class random forest classifier (Figure 1D). FoodProX takes as input the list of nutrients in any food and offers as output a vector of four probabilities $\left\{p_{i}\right\}$, representing the likelihood that the respective food is classified as unprocessed $\left(p_{1}\right.$, NOVA 1$)$, culinary ingredient $\left(p_{2}\right.$, NOVA 2$)$, processed $\left(p_{3}\right.$, NOVA 3$)$, and ultra-processed $\left(p_{4}\right.$, NOVA 4$)$. The highest of the four probabilities determines the final classification label for each food (Figure 1C-D).

As $90 \%$ of foods in USDA Branded Food Products Database report less than 17 nutrients, we also tested the algorithm's predictive power with the 12 gram-based nutrients mandated by FDA [31] (SI Section 1). We identified, consistently high AUC values in all cases: $0.9804 \pm 0.0012$ for NOVA $1,0.9632 \pm 0.0024$ for NOVA $2,0.9696 \pm 0.0018$ for NOVA $3,0.9789 \pm 0.0015$ for NOVA 4 (Figure S4 and Table S6). These results confirm that the degree and combinations of changes in nutrient contents can have significant predictive power to ascertain the extent of food processing.

We visualize the decision space of the classifier by performing a principal component analysis over the probabilities $\left\{p_{i}\right\}$, observing that the list of foods manually classified by NOVA is limited to the three corners of the phase space, to which the classifier assigns dominating probabilities (Figure 2A). We used FoodProX to classify all foods and beverages that lacked prior manual NOVA classification in FNDDS (65.75\% of total). We found that $7.39 \%$ of FNDDS consists of NOVA $1 ; 0.90 \%$, NOVA $2 ; 18.36 \%$, NOVA 3 ; and $73.35 \%$, NOVA 4 foods (Figure 2B). Yet, many previously unclassified foods are often inside the phase space, indicating that they lack a dominating probability, hence the assignment of a single NOVA class is somewhat arbitrary (Figure 2B). The detection of this ambiguity is a strength of FoodProX, reflecting the observation that a four-class classification does not accurately capture the nutrient variability characterized by different food processing methods and intensities [32]. For example, while the classifier confidently assigns "Raw Onion" to NOVA $1\left(p_{1}=0.9651\right)$, and "Onion rings prepared from frozen" $\left(p_{4}=0.9921\right)$ to NOVA 4 , it accurately offers an intermediate confidence for "Onion, Sauteed," placing it with probability $p_{4}=0.6521$ in NOVA 4 , and with probability $p_{3}=0.2488$ in NOVA 3. 
medRxiv preprint doi: https://doi.org/10.1101/2021.05.22.21257615; this version posted May 25, 2021. The copyright holder for this preprint (which was not certified by peer review) is the author/funder, who has granted medRxiv a license to display the preprint in perpetuity.

\section{Food Processing Score (FPro)}

The observation that enforcing discrete classes causes inherent challenges in food classification prompted us to introduce the Food Processing Score (FPro), a continuous variable with $F$ Pro $=0$ for raw ingredients, and FPro $\rightarrow 1$ for ultra-processed foods. We define the FPro of a food $k$ as

$$
\text { Pro }_{k}=\frac{1-p_{1}^{k}+p_{4}^{k}}{2}
$$

capturing the progressive changes in nutrient content induced by processing. For example, FPro incrementally increases from raw onion $(F P r o=0.0203)$ to boiled onion $(F P r o=0.3126)$, fried onion $($ F Pro $=0.7779)$, and onion rings from frozen ingredients $($ F Pro $=0.9955$, Figure $2 \mathrm{C})$. FPro allows us to unveil the degree of processing characterizing different food preparation techniques, assigning lower values to foods made from fresh ingredients than those made from frozen ingredients (Figure 2C). FPro also permits classification of complex recipes and mixed dishes, identifying the overall average processing of the item or meal.

As noted above, nearly $20 \%$ of the U.S. diet comprises foods in NOVA 3, and over $70 \%$, in NOVA 4. The observed variability of FPro for foods that belong in the same NOVA class prompted us to analyze the variations in degree of processing within subgroups of foods and beverages, as captured by What We Eat in America (WWEIA) categorization [33]. We find that different food products within the same NOVA classification and WWEIA categories show remarkable variability in FPro, confirming the presence of different processing fingerprints within each category (Figure 2D). For example, if we select four products from the same brand (Post) of breakfast cereals that are all manually classified as NOVA 4 (i.e., considered identically processed), we observe that F Pro differentiate them and captures progressive alterations in fiber content, fortification with vitamins and minerals, and addition of sugar and fats (Figure 2D, insert).

\section{Individual Processing Score}

The significant contribution of ultra-processed food to American dietary intake, and F Pro's ability to demonstrate heterogeneity in the extent of food processing within the broad category of ultra-processed food, prompts us to assess the contribution of processed food to the diet of each individual, jointly weighted by both the extent of processing and the contribution to caloric intake. This is provided by the individual Food Processing Score (iF Pro), 


$$
i F \operatorname{Pro}_{W C}^{j}=\sum_{k}^{D_{j}} \frac{c_{k}^{j}}{C^{j}} \text { Pro }_{k},
$$

which varies between 0 and 1 , where $D_{j}$ is the number of dishes consumed by individual $j, C^{j}$ is the daily total amount of consumed calories, and $c_{k}^{j}$ is the amount of calories contributed by each food item. A gram-based $i F P{ } o_{W G}$, captures the fraction of grams in a diet supplied by processed food (Eq. S4).

We calculated iFPro for 20,047 individuals with dietary records in a representative U.S. national sample from NHANES 1999-2006. As Figure 3C shows, the median iF Pro ${ }_{W C}$ for the American population is 0.7872 , confirming a high reliance on intake on ultra-processed food [24-26]. More importantly, iF Pro allows us to identify differential reliance on processed food. Consider individuals $\mathcal{A}$ and $\mathcal{B}$, men of similar age (47 vs. 48 years old, Figure 3A-C), with similar number of reported daily unique dishes (12.5 vs. 13 dishes) and comparable caloric intake $(2,016$ vs. $1,894 \mathrm{kcal})$. Yet, the diet of individual $\mathcal{A}$ has $i F \operatorname{Pro}_{W C}=0.3981$, as it relies on unprocessed ingredients and home cooking. In contrast, $\mathcal{B}$ has $i F \operatorname{Pro}_{W C}=0.9572$, given his consumption of hot dogs, hamburgers, French fries, pizza, and Kit Kat. As we show next, these differences correlate with different health outcomes.

\section{Health Implications}

To quantify the degree to which the consumption of ultra-processed foods, graded across their entire range, correlate with health outcomes, we investigated exposures and phenotypes provided in NHANES 1999-2006 [34]. We measured for each variable the association with the diet processing score iFPro, adjusting for age, sex, ethnicity, socio-economic status, BMI and caloric intake (Figure SI 3). After False Discovery Rate (FDR) correction for multiple testing, 209 variables survive (SI Section 4), documenting how the consumption of ultra-processed foods relates to health.

Metabolic and Cardiovascular Risk: We find that individuals with a high food processing score show positive associations with risk of metabolic syndrome (MetS), diabetes (fasting glucose), and also (consistent with poor diets clustering in families) a family history of heart attack or angina, in line with earlier findings (SI Section 4) [35-37]. The increased risk of cardiovascular disease is further confirmed by the significant positive association of iF Pro with 
medRxiv preprint doi: https://doi.org/10.1101/2021.05.22.21257615; this version posted May 25 , 2021 . The copyright holder for this preprint

both Framingham and ACC/AHA Risk Scores (Figure 3D) [38, 39].

Overall, individuals with a higher food processing score exhibit higher blood pressure, trunk fat and subscapular skinfold, measures of obesity, and blood insulin and triglyceride levels; and lower "good" HDL cholesterol. Further novel findings indicate a higher prevalence of type 2 diabetes (C-peptide), inflammation (C-Reactive Protein), vitamin deficiency (homocysteine, methylmalonic acid), and inflammatory arthritis [40-45]. We also find an inverse association between iFPro and telomere length, which can be affected by diet through inflammation and oxidation [46], suggesting a higher biological age for individuals with higher reliance on more ultra-processed foods (SI Section 4).

Vitamins and Phytoestrogens: A greater consumption of more extensively processed foods correlates with lower levels of vitamins in our blood stream, like Vitamin $B_{12}$ and Vitamin C, despite the fact that ultra-processed breakfast cereals and refined flours are frequently fortified with these vitamins and minerals.

In addition, iF Pro allows us to discriminate plant-based diets relying on legumes, whole grains, fruits and vegetables, from diets that include ultra-processed plant-based meat, dairy substitutes, and plant-based drinks [47]. For example, we observe a positive correlation between $i F$ Pro $_{W C}$ and the urine levels of daidzein, genistein, and their bacterial metabolite o-desmethylangolensin - all bio-markers of soy, abundant in diets that rely on highly processed soy protein foods. On the other hand, enterolactone and enterodiol, gut metabolites of plant lignans (fiber-associated compounds found in many plant families and common foods, including grains, nuts, seeds, vegetables, and drinks such as tea, coffee or wine) are inversely associated with $i$ Pro $_{W C}[48]$.

Chemical Exposures: Diet rich in highly processed food shows association with increased carcinogenic, diabetic, and obesity-inducing food additives and neoformed contaminants, several of which represent previously unknown relationships. For instance, we find positive associations with acrylamide and polycyclic aromatic hydrocarbons, present in heat treated processed food products as a result of Maillard reaction, benzenes (abundant in soft drinks), furans (common in canned and jarred foods), PCBs (processed meat products), perfluorooctanoic acids and phthalates (found in the wrappers of some fast foods, microwavable popcorn, and candy), and environmental phenols like the endocrine disruptor bisphenol A (linked to plastics and resins for food packaging) [49-54]. Importantly, all these represent compounds not reported in food composition databases, but recovered in blood and urine (Figure SI 5). 
medRxiv preprint doi: https://doi.org/10.1101/2021.05.22.21257615; this version posted May 25, 2021. The copyright holder for this preprint (which was not certified by peer review) is the author/funder, who has granted medRxiv a license to display the preprint in perpetuity.

It is made available under a CC-BY-NC-ND 4.0 International license .

Taken together, our ability to distinguish the degree of processing of foods in individual diets allowed us to unveil multiple correlations between diets with greater reliance on ultra-processing and health outcomes. This approach leads to results that cannot be captured with the existing NOVA classification (SI Section 4). Specifically, if we rely on the manual NOVA 4 and the panel of exposures in NHANES, we recover only 92 significant associations. Among the missing associations are the inverse correlation of a more ultra-processed diet with vitamin $\mathrm{D}$ and folate blood levels, and the positive correlation with c-peptide, homocysteine, and blood pressure (SI Section 4).

\section{Food Substitution}

The high reliance of ultra-processed food among the U.S. population (Figure 3C) prompts us to ask: what kind of interventions could help us reduce the observed health implications? Given the challenges of large behavioral shifts $[55,56]$, here we assume that an individual does not need to overhaul her entire diet, but replace the most processed items she consumes with less processed versions of the same item. To minimize the dietary shifts required, we identify within each individual's diet the item with high caloric contribution and for which there are significantly less processed alternatives (Eq. S5), preserving the broad food class (WWEIA) of the initial choice (SI Section 5). For example, we replace Kix cereals $(F$ Pro $=0.9998)$ with shredded wheat and bran cereals $(F$ Pro $=0.5091)$, and spread cheese from a pressurized can $(F$ Pro $=0.9648)$ with provolone cheese $($ F Pro $=0.5001)$.

We find that the isocaloric replacement of a single item from the average of 19.28 food items daily consumed by U.S. adults reduces the median $i F$ Pro $_{W C}$ by $12.15 \%$, from an overall score of 0.7872 to 0.6915 (Figure 3E). Based on observed associations with phenotypes, this translate to a decrease in the odds of metabolic syndrome by $12.25 \%$, a lower concentration of urinary bisphenol A by $8.47 \%$; and an increased blood concentration of vitamin $B_{12}$ and vitamin C by $4.83 \%$ and 12.31\%, respectively (Figure 3F and Eqs. S6 and S7). Furthermore, the substitution of 10 food items, about half the daily reported items, leads to $37.03 \%$ decrease in $i$ Pro $_{W C}$, with associated changes of $-21.43 \%$ for bisphenol A, $+13.02 \%$ for blood vitamin $B_{12}$, and $+37.26 \%$ for blood vitamin C.

Overall, we find that modest substitution strategies made possible by FPro can preserve the general nature of an individual's diet but reduce reliance on more highly processed food and successfully moderate the observed health implications. To implement such strategies, 
medRxiv preprint doi: https://doi.org/10.1101/2021.05.22.21257615; this version posted May 25, 2021. The copyright holder for this preprint

(which was not certified by peer review) is the author/funder, who has granted medRxiv a license to display the preprint in perpetuity.

It is made available under a CC-BY-NC-ND 4.0 International license .

consumers must be empowered with information on the degree of processing characterizing the foods and beverages they purchase or make, and the available alternatives, information provided by FPro for the whole food supply.

\section{Discussion}

The remarkable ability of the FoodProX predictions to replicate the manual NOVA classification confirms that food processing results in distinct patterns of nutrient alterations, accurately detected by machine learning. Importantly, FoodProX allows us to build upon and extend the current NOVA classification in several crucial respects, offering automated classification of foods across multiple national and commercial databases, ability to classify complex recipes and mixed foods and meals, and ability to quantify the extent of food processing among the large and otherwise homogeneously categorized groups of ultra-processed foods. Given that our algorithm only needs the Nutrition Facts, information already accessible to consumers on packaging and via smartphone apps, web portals, and grocery store and restaurant websites, FPro can help monitor the reliance of an individual's diet on less or more processed food. Differently from dietary indexes such as HEI-15 [57], designed to measure the alignment of individuals' diets with the 2015-2020 Dietary Guidelines for Americans, iF Pro and F Pro helps us identify which foods to substitute, to shift individual consumption patterns towards a less processed diet. Our substitution heuristic indicates that minimal changes in diet can significantly reduce disease risk, a strategy hard to implement with the current NOVA classification, which classifies more than $70 \%$ of the food supply as NOVA 4 [58]. Overall, a combination of FPro with epidemiological studies and food classification could lead to an automated and practical pipeline capable of systematically improving population diet and individual health. 
medRxiv preprint doi: https://doi.org/10.1101/2021.05.22.21257615; this version posted May 25, 2021. The copyright holder for this preprint (which was not certified by peer review) is the author/funder, who has granted medRxiv a license to display the preprint in perpetuity.

It is made available under a CC-BY-NC-ND 4.0 International license.

\section{Acknowledgments}

We thank Dr. Euridice Martinez Steele at the University of Sao Paulo for providing NOVA manual classification for FNDDS databases. We thank Dr. Wei Wang at Harvard Medical School for consulting as statistical expert. This work was conducted with support from Harvard Catalyst | The Harvard Clinical and Translational Science Center (National Center for Advancing Translational Sciences, National Institutes of Health Award UL 1TR002541) and financial contributions from Harvard University and its affiliated academic healthcare centers. The content is solely the responsibility of the authors and does not necessarily represent the official views of Harvard Catalyst, Harvard University and its affiliated academic healthcare centers, or the National Institutes of Health. A.-L.B is partially supported by NIH grant 1P01HL132825, American Heart Association grant 151708, and ERC grant 810115-DYNASET.

\section{Competing Interests}

A.-L.B. is the founder of Scipher Medicine and Foodome, companies that explore the use of network-based tools in health, and Datapolis, that focuses on urban data.

\section{Code and Data Availability}

All codes are available upon request at g.menichetti@northeastern.edu. All datasets can be accessed through the cited references.

\section{Author contributions}

G.M. and A.-L.B. conceived the project. G.M. designed the study, performed data modeling, analytical calculations, data query and integration, and wrote the manuscript. B.R. performed data query, data integration, statistical analysis, and contributed to writing the manuscript. D.M. contributed to interpreting the results and writing the manuscript. A.-L.B. contributed to the conceptual design of the study and writing the manuscript. 
medRxiv preprint doi: https://doi.org/10.1101/2021.05.22.21257615; this version posted May 25, 2021. The copyright holder for this preprint (which was not certified by peer review) is the author/funder, who has granted medRxiv a license to display the preprint in perpetuity.

\section{References}

[1] Tapsell, L. C., Neale, E. P., Satija, A. \& Hu, F. B. Foods, Nutrients, and Dietary Patterns: Interconnections and Implications for Dietary Guidelines. Advances in Nutrition 7, 445-454 (2016).

[2] Willett, W. et al. Food in the Anthropocene: the EAT-Lancet Commission on healthy diets from sustainable food systems. The Lancet 393, 447-492 (2019).

[3] MyPyramid. https://www.fns.usda.gov/mypyramid.

[4] Choose My Plate. https://www.choosemyplate.gov.

[5] Fraanje, W. \& Garnett, T. What is ultra-processed food? And why do people disagree about its utility as a concept? (Foodsource: building blocks). Encyclopedic Dictionary of Polymers 98-98 (2019).

[6] Brazilian Dietary Guidelines (2015). URL http://www.fao.org/nutrition/education/ food-based-dietary-guidelines/regions/countries/brazil/en/.

[7] Spector, T. D. \& Gardner, C. D. Challenges and opportunities for better nutrition sciencean essay by Tim Spector and Christopher Gardner. BMJ (Clinical research ed.) 369, m2470 (2020). URL http://dx.doi.org/10.1136/bmj.m2470.

[8] Lustig, R. H. Processed food-an experiment that failed. JAMA Pediatrics 171, 212-214 (2017). URL http://www.npc.umich.

[9] Forouhi, N. G., Misra, A., Mohan, V., Taylor, R. \& Yancy, W. Dietary and nutritional approaches for prevention and management of type 2 diabetes. BMJ (Online) 361, k2234-k2234 (2018). URL https://europepmc.org/articles/PMC5998736https: //europepmc.org/article/pmc/5998736.

[10] Cordain, L. et al. Origins and evolution of the Western diet: health implications for the 21st century. The American Journal of Clinical Nutrition 81, 341-354 (2005). URL https: //doi.org/10.1093/ajcn.81.2.341. https://academic.oup.com/ajcn/article-pdf/81/ 2/341/23874879/341.pdf.

[11] Monteiro, C. A. et al. The UN Decade of Nutrition, the NOVA food classification and the trouble with ultra-processing. Public Health Nutrition 21, 5-17 (2018).

[12] Monteiro, C. A. et al. NOVA. The star shines bright. World Nutrition 7, 28-38 (2016). 
medRxiv preprint doi: https://doi.org/10.1101/2021.05.22.21257615; this version posted May 25, 2021. The copyright holder for this preprint (which was not certified by peer review) is the author/funder, who has granted medRxiv a license to display the preprint in perpetuity.

It is made available under a CC-BY-NC-ND 4.0 International license .

[13] Steele, E. M. et al. Ultra-processed foods and added sugars in the US diet: Evidence from a nationally representative cross-sectional study. BMJ Open 6, 1-8 (2016).

[14] Steele, E. M. \& Monteiro, C. A. Association between dietary share of ultra-processed foods and urinary concentrations of phytoestrogens in the US. Nutrients 9 (2017).

[15] Adjibade, M. et al. Prospective association between ultra-processed food consumption and incident depressive symptoms in the French NutriNet-Santé cohort. BMC Medicine 17, $1-13(2019)$.

[16] Fiolet, T. et al. Consumption of ultra-processed foods and cancer risk: Results from NutriNet-Santé prospective cohort. BMJ (Online) $\mathbf{3 6 0}$ (2018).

[17] Srour, B. et al. Ultra-processed food intake and risk of cardiovascular disease: Prospective cohort study (NutriNet-Santé). The BMJ 365 (2019).

[18] Hall, K. D. et al. Ultra-Processed Diets Cause Excess Calorie Intake and Weight Gain: An Inpatient Randomized Controlled Trial of Ad Libitum Food Intake. Cell Metabolism 30, 1-11 (2019). URL https://doi.org/10.1016/j.cmet.2019.05.008.

[19] Vandevijvere, S. et al. Global trends in ultraprocessed food and drink product sales and their association with adult body mass index trajectories. Obesity Reviews 20, 10-19 (2019). URL https://onlinelibrary.wiley.com/doi/abs/10.1111/obr.12860. https: //onlinelibrary.wiley.com/doi/pdf/10.1111/obr.12860.

[20] Zhang, Z., Jackson, S. L., Martinez, E., Gillespie, C. \& Yang, Q. Association between ultraprocessed food intake and cardiovascular health in us adults: a cross-sectional analysis of the nhanes 2011-2016. The American Journal of Clinical Nutrition 113, 428436 (2020). URL https://doi.org/10.1093/ajcn/nqaa276. https://academic.oup.com/ ajcn/article-pdf/113/2/428/36170430/nqaa276.pdf.

[21] Micha, R., Wallace, S. K. \& Mozaffarian, D. Red and processed meat consumption and risk of incident coronary heart disease, stroke, and diabetes mellitus: A systematic review and meta-analysis. Circulation 121, 2271-2283 (2010).

[22] Monteiro, C. A. et al. Ultra-processed foods: what they are and how to identify them. Public Health Nutrition 22, 936-941 (2019).

[23] Meneguelli, T. S. et al. Food consumption by degree of processing and cardiometabolic risk: a systematic review. International Journal of Food Sciences and Nutrition 71, 678- 
medRxiv preprint doi: https://doi.org/10.1101/2021.05.22.21257615; this version posted May 25, 2021. The copyright holder for this preprint (which was not certified by peer review) is the author/funder, who has granted medRxiv a license to display the preprint in perpetuity. It is made available under a CC-BY-NC-ND 4.0 International license .

692 (2020). URL https://doi.org/10.1080/09637486.2020.1725961. PMID: 32053758, https://doi.org/10.1080/09637486.2020.1725961.

[24] Lane, M. M. et al. Ultraprocessed food and chronic noncommunicable diseases: A systematic review and meta-analysis of 43 observational studies. Obesity Reviews 1-19 (2020).

[25] Martínez Steele, E., Popkin, B. M., Swinburn, B. \& Monteiro, C. A. The share of ultraprocessed foods and the overall nutritional quality of diets in the US: Evidence from a nationally representative cross-sectional study. Population Health Metrics 15, 1-11 (2017). NIHMS150003.

[26] Gupta, S., Hawk, T., Aggarwal, A. \& Drewnowski, A. Characterizing ultra-processed foods by energy density, nutrient density, and cost. Frontiers in Nutrition 6 (2019). URL https://www.frontiersin.org/article/10.3389/fnut.2019.00070/full.

[27] USDA FoodData Central. https://fdc.nal.usda.gov/.

[28] Ahuja, J. et al. USDA Food and Nutrient Database for Dietary Studies, 5.0. U.S. Department of Agriculture, Agricultural Research Service, Food Surveys Research Group, Beltsville, MD. http://www.ars.usda.gov/ba/bhnrc/fsrg (2012).

[29] Sebastian, R. S. et al. Flavonoid Values for USDA Survey Foods and Beverages 2007-2010. U.S. Department of Agriculture, Agricultural Research Service, Food Surveys Research Group, Beltsville, MD. http://www.ars.usda.gov/nea/bhnrc/fsrg (2016).

[30] Menichetti, G. \& Barabasi, A.-L. Universal Scaling of Nutrient Concentrations in Food. Submitted for publication (Nature Food) 1-66 (2021).

[31] FDA Nutrition Facts. https://www.fda.gov/media/99331/download.

[32] Davidou, S., Christodoulou, A., Frank, K. \& Fardet, A. A study of ultra-processing marker profiles in 22,028 packaged ultra-processed foods using the siga classification. Journal of Food Composition and Analysis 99, 103848 (2021). URL https: //www.sciencedirect.com/science/article/pii/S088915752100048X.

[33] Rhodes, D. G., Adler, M. E., Clemens, J. C. \& Moshfegh, A. J. What we eat in America food categories and changes between survey cycles. Journal of Food Composition and Analysis 64, 107-111 (2017). URL http://dx.doi.org/10.1016/j.jfca.2017.07.018.

[34] Patel, C. J. et al. A database of human exposomes and phenomes from the us national health and nutrition examination survey. Scientific Data 3, 160096 (2016). URL https: //doi.org/10.1038/sdata.2016.96. 
medRxiv preprint doi: https://doi.org/10.1101/2021.05.22.21257615; this version posted May 25, 2021. The copyright holder for this preprint (which was not certified by peer review) is the author/funder, who has granted medRxiv a license to display the preprint in perpetuity. It is made available under a CC-BY-NC-ND 4.0 International license .

[35] Nardocci, M., Polsky, J. Y. \& Moubarac, J. C. Consumption of ultra-processed foods is associated with obesity, diabetes and hypertension in Canadian adults. Canadian Journal of Public Health 1-9 (2020). URL https://doi.org/10.17269/s41997-020-00429-9.

[36] De Deus Mendonça, R. et al. Ultra-processed food consumption and the incidence of hypertension in a mediterranean cohort: The seguimiento universidad de navarra project. American Journal of Hypertension 30, 358-366 (2017). URL https://pubmed.ncbi.nlm.nih.gov/ $27927627 /$.

[37] Milanlouei, S. et al. A systematic comprehensive longitudinal evaluation of dietary factors associated with acute myocardial infarction and fatal coronary heart disease. Nature Communications 11, 1-14 (2020). URL https://doi.org/10.1038/s41467-020-19888-2.

[38] D'Agostino, R. B. et al. General cardiovascular risk profile for use in primary care: The Framingham heart study. Circulation 117, 743-753 (2008).

[39] Goff, D. C. et al. 2013 ACC/AHA guideline on the assessment of cardiovascular risk: A report of the American college of cardiology/American heart association task force on practice guidelines. Circulation 129, 49-73 (2014).

[40] de Miranda, R. C., Rauber, F. \& Levy, R. B. Impact of ultra-processed food consumption on metabolic health. Current Opinion in Lipidology 32, 24-37 (2021).

[41] Yang, Q., Zhang, Z., Steele, E. M., Moore, L. V. \& Jackson, S. L. Ultra-processed foods and excess heart age among u.s. adults. American Journal of Preventive Medicine 59, e197-e206 (2020). URL https://www.sciencedirect.com/science/article/pii/ S0749379720302889.

[42] Bonaccio, M. et al. Ultra-processed food consumption is associated with increased risk of all-cause and cardiovascular mortality in the Moli-sani Study. The American Journal of Clinical Nutrition 113, 446-455 (2020). URL https://doi.org/10.1093/ajcn/nqaa299. https://academic.oup.com/ajcn/article-pdf/113/2/446/36170506/nqaa299.pdf.

[43] Martínez Leo, E. E. \& Segura Campos, M. R. Effect of ultra-processed diet on gut microbiota and thus its role in neurodegenerative diseases. Nutrition 71, 110609 (2020). URL https://www.sciencedirect.com/science/article/pii/S0899900719301923.

[44] Neri, D., Martinez-Steele, E., Monteiro, C. A. \& Levy, R. B. Consumption of ultra-processed foods and its association with added sugar content in the diets of us children, nhanes 2009-2014. Pediatric Obesity 14, e12563 (2019). URL https: 
medRxiv preprint doi: https://doi.org/10.1101/2021.05.22.21257615; this version posted May 25, 2021. The copyright holder for this preprint (which was not certified by peer review) is the author/funder, who has granted medRxiv a license to display the preprint in perpetuity. It is made available under a CC-BY-NC-ND 4.0 International license .

//onlinelibrary.wiley.com/doi/abs/10.1111/ijpo.12563. E12563 IJPO-2019-0182, https://onlinelibrary.wiley.com/doi/pdf/10.1111/ijpo.12563.

[45] Cheung, C.-L., Tan, K. C. B., Lam, K. S. L. \& Cheung, B. M. Y. The Relationship Between Glucose Metabolism, Metabolic Syndrome, and Bone-Specific Alkaline Phosphatase: A Structural Equation Modeling Approach. The Journal of Clinical Endocrinology 83 Metabolism 98, 3856-3863 (2013). URL https://doi.org/10.1210/jc.20132024. https://academic.oup.com/jcem/article-pdf/98/9/3856/11127694/1.jc-132024\_tab3.pdf.

[46] Alonso-Pedrero, L. et al. Ultra-processed food consumption and the risk of short telomeres in an elderly population of the Seguimiento Universidad de Navarra (SUN) Project. The American journal of clinical nutrition 111, 1259-1266 (2020). URL https://academic.oup.com/ajcn/article/111/6/1259/5824715.

[47] Gehring, J. et al. Consumption of Ultra-Processed Foods by Pesco-Vegetarians, Vegetarians, and Vegans: Associations with Duration and Age at Diet Initiation. The Journal of nutrition 151, 120-131 (2021).

[48] Lampe, J. W. Isoflavonoid and lignan phytoestrogens as dietary biomarkers. Journal of Nutrition 133, 956S-964S (2003). URL https://academic.oup.com/jn/article/133/3/ 956S/4688069.

[49] Martínez Steele, E., Khandpur, N., da Costa Louzada, M. L. \& Monteiro, C. A. Association between dietary contribution of ultra-processed foods and urinary concentrations of phthalates and bisphenol in a nationally representative sample of the us population aged 6 years and older. PLOS ONE 15, 1-21 (2020). URL https://doi.org/10.1371/ journal.pone.0236738.

[50] Nerín, C., Aznar, M. \& Carrizo, D. Food contamination during food process. Trends in Food Science 83 Technology 48, 63-68 (2016). URL https://www.sciencedirect.com/ science/article/pii/S0924224415301370.

[51] Rather, I. A., Koh, W. Y., Paek, W. K. \& Lim, J. The sources of chemical contaminants in food and their health implications. Frontiers in Pharmacology 8, 830 (2017). URL https://www.frontiersin.org/article/10.3389/fphar.2017.00830.

[52] Jain, R. B. \& Wang, R. Y. Association of caffeine consumption and smoking status with the serum concentrations of polychlorinated biphenyls, dioxins, and furans in the general 
medRxiv preprint doi: https://doi.org/10.1101/2021.05.22.21257615; this version posted May 25, 2021. The copyright holder for this preprint (which was not certified by peer review) is the author/funder, who has granted medRxiv a license to display the preprint in perpetuity.

It is made available under a CC-BY-NC-ND 4.0 International license .

u.s. population: Nhanes 2003-2004. Journal of Toxicology and Environmental Health, Part A 74, 1225-1239 (2011). URL https://doi.org/10.1080/15287394.2011.587105. PMID: 21797774 , https://doi.org/10.1080/15287394.2011.587105.

[53] Arisseto, A. P. Chapter 21 - furan in processed foods. In Kotzekidou, P. (ed.) Food Hygiene and Toxicology in Ready-to-Eat Foods, 383-396 (Academic Press, San Diego, 2016). URL https://www.sciencedirect.com/science/article/pii/B9780128019160000212.

[54] Buckley, J. P., Kim, H., Wong, E. \& Rebholz, C. M. Ultra-processed food consumption and exposure to phthalates and bisphenols in the us national health and nutrition examination survey, 2013-2014. Environment International 131, 105057 (2019). URL https://www.sciencedirect.com/science/article/pii/S0160412019317416.

[55] Hunter, R. F. et al. Social network interventions for health behaviour change: a systematic review. The Lancet 390, S47 (2017). URL www.thelancet.com.

[56] Salvy, S. J., de la Haye, K., Bowker, J. C. \& Hermans, R. C. Influence of peers and friends on children's and adolescents' eating and activity behaviors. Physiology and Behavior 106, 369-378 (2012).

[57] National cancer institute. developing the healthy eating index. bethesda, md: National cancer institute. https://epi.grants.cancer.gov/hei/developing.html. 2020 (accessed September 1, 2020).

[58] Baldridge, A. S. et al. The Healthfulness of the US Packaged Food and Beverage Supply: A Cross-Sectional Study. Nutrients 11, 1704 (2019). 
medRxiv preprint doi: https://doi.org/10.1101/2021.05.22.21257615; this version posted May 25, 2021. The copyright holder for this preprint (which was not certified by peer review) is the author/funder, who has granted medRxiv a license to display the preprint in perpetuity.

It is made available under a CC-BY-NC-ND 4.0 International license.

a

Onions, mature, cooked or sauteed from fresh, fat added in cooking

b Onions, rings, from frozen, batter-dipped, baked or fried

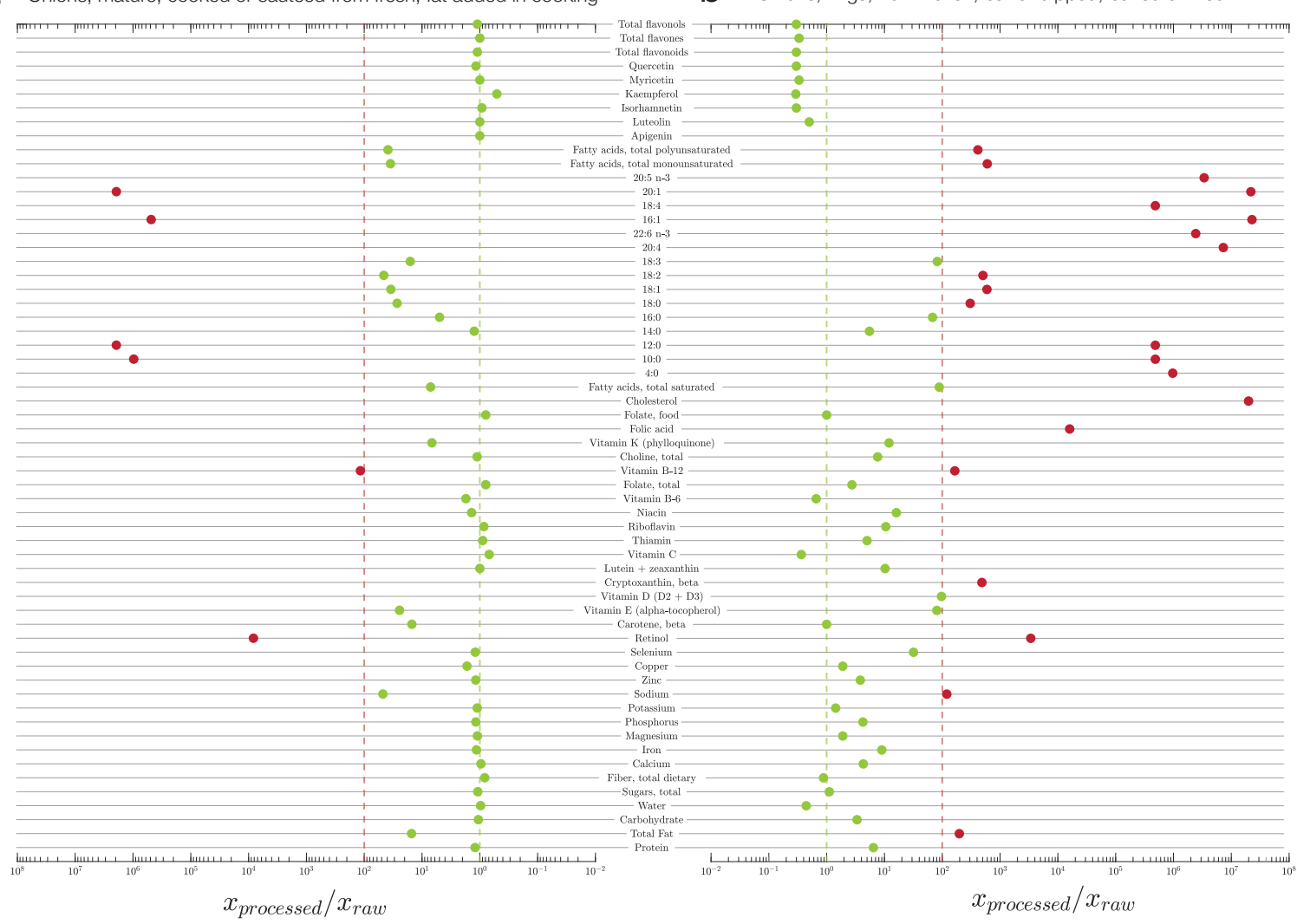

C

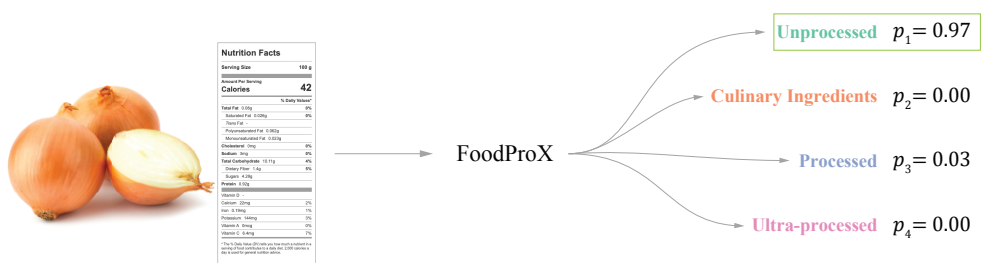

d

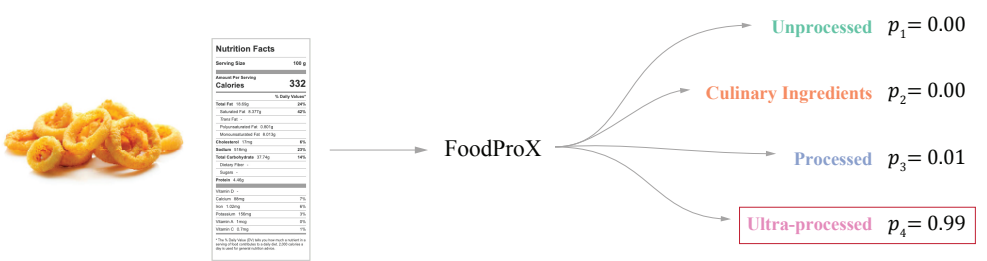

Figure 1

Figure 1: Food Processing and Nutrient Changes (FoodProX). (a)-(b) Ratio of nutrient concentrations for $100 \mathrm{~g}$ of Sauteed Onion and Onion Rings compared to Raw Onion, indicating how processing alters the concentration of multiple nutrients. (c)-(d) We trained FoodProX, a random forest classifier over the nutrient concentrations within $100 \mathrm{~g}$ of each food, tasking it to predict its processing level according to NOVA. FoodProX represents each food by a vector of probabilities $\left\{p_{i}\right\}$, capturing the likelihood of being classified as unprocessed (NOVA 1), culinary ingredient (NOVA 2), processed (NOVA 3), and ultra-processed (NOVA 4). The highest probability determines the final classification label, highlighted in a box on the right. 
medRxiv preprint doi: https://doi.org/10.1101/2021.05.22.21257615; this version posted May 25, 2021. The copyright holder for this preprint (which was not certified by peer review) is the author/funder, who has granted medRxiv a license to display the preprint in perpetuity.

It is made available under a CC-BY-NC-ND 4.0 International license .

a

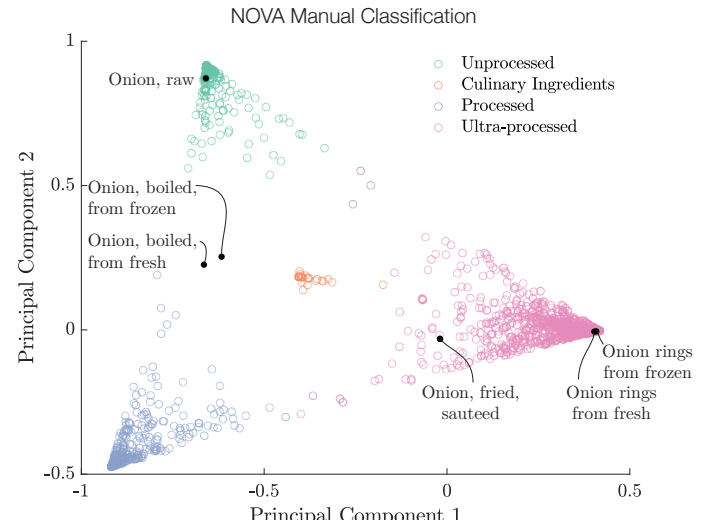

b

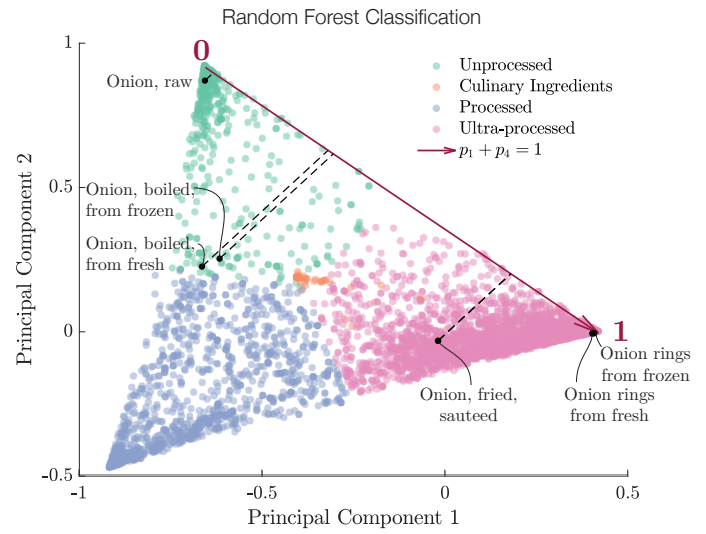

C

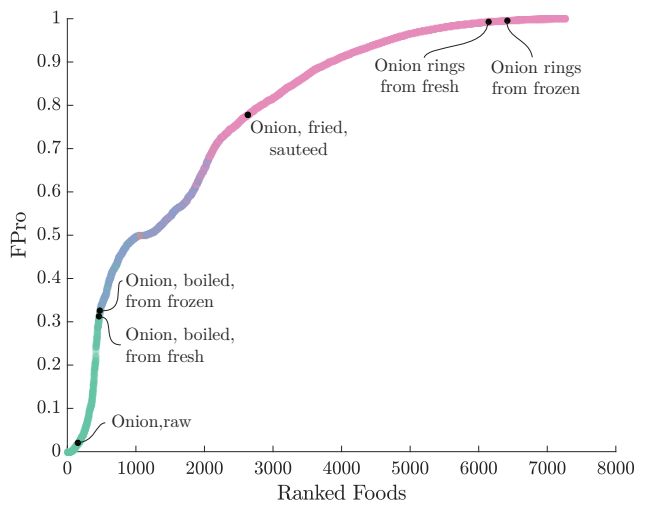

d
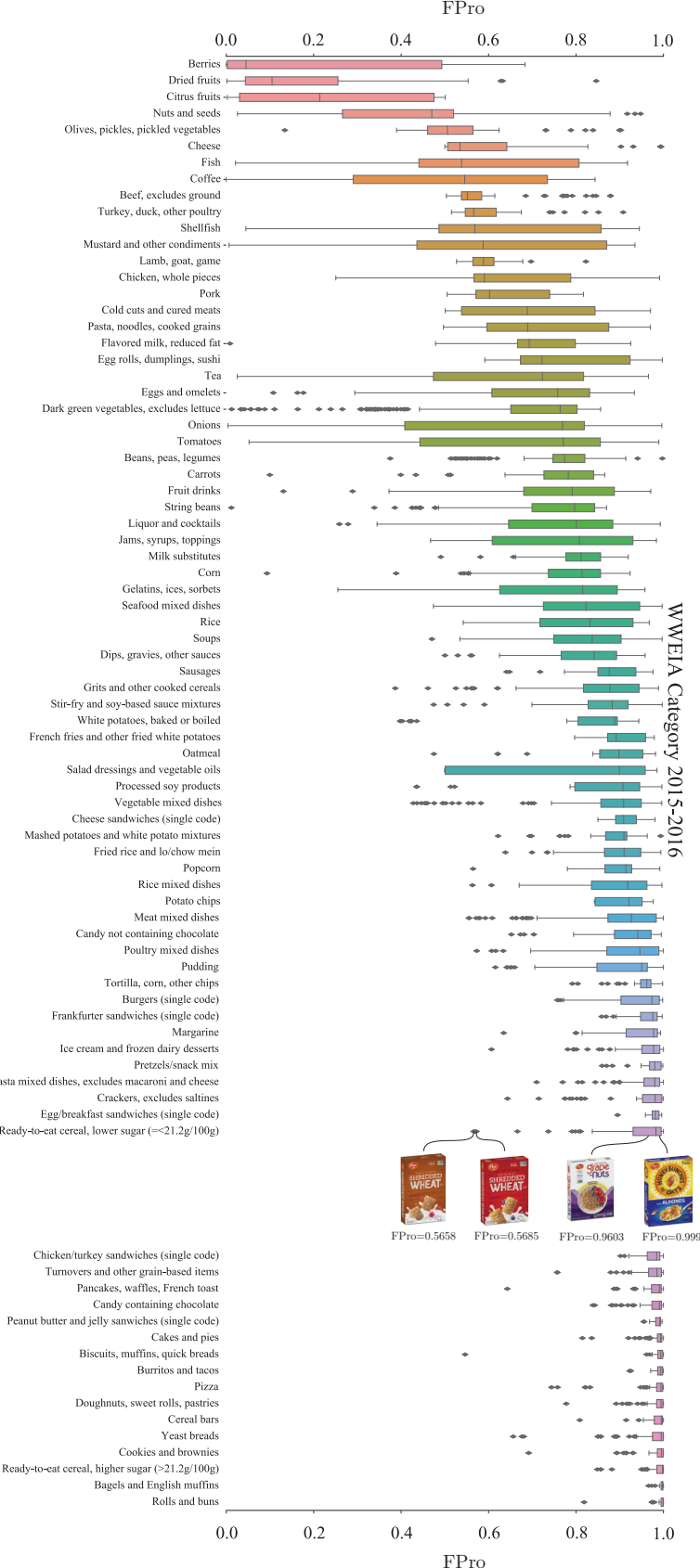

Figure 2 
medRxiv preprint doi: https://doi.org/10.1101/2021.05.22.21257615; this version posted May 25, 2021. The copyright holder for this preprint

(which was not certified by peer review) is the author/funder, who has granted medRxiv a license to display the preprint in perpetuity.

It is made available under a CC-BY-NC-ND 4.0 International license.

Figure 2: NOVA Classification and Processing Score. (a) Visualization of the decision space of FoodProX via principal component analysis of the probabilities $\left\{p_{i}\right\}$. The manual 4-level NOVA classification assigns unique labels to only $34.25 \%$ of the foods listed in FNDDS 2009-2010 (empty circles). The classification of the remaining foods remains unknown ("Not Classified"), or must be further decomposed into ingredients ("Composite Recipe"). The list of foods manually classified by NOVA is largely limited to the three corners of the phase space, foods to which the classifier assigns dominating probabilities. (b) FoodProX assigned NOVA labels to all foods in FNDDS 2009-2010. The symbols at the boundary regions indicates that for these foods the algorithm's confidence in the classification is not high, hence a 4-class classification does not capture the degree of processing characterizing that food. For each food $k$, the processing score $F_{\text {Pro }}$ represents the orthogonal projection (black dashed lines) of $\vec{p}^{k}=\left(p_{1}^{k}, p_{2}^{k}, p_{3}^{k}, p_{4}^{k}\right)$ onto the line $p_{1}+p_{4}=1$ (highlighted in dark red). (c) We ranked all foods in FNDDS 2009/2010 according to FPro. The measure sorts onion products in increasing order of processing, from "Onion, Raw", to "Onion rings, from frozen". (d) Distribution of FPro for a selection of the 155 Food Categories in What We Eat in America (WWEIA) 2015-2016 with at least 20 items (SI Section 2). WWEIA categories group together foods and beverages with similar usage and nutrient content in the U.S. food supply [33]. All categories are ranked in increasing order of median FPro, indicating that within each food group, we have remarkable variability in FPro, confirming the presence of different degrees of processing. We illustrate this through four ready-to-eat cereals, all manually classified as NOVA 4, yet with rather different FPro. While the differences in the nutrient content of Post Shredded Wheat 'n Bran $(F$ Pro $=0.5658)$ and Post Shredded Wheat $(F$ Pro $=0.5685)$ are minimal, with lower fiber content for the latter, the fortification with vitamins, minerals, and the addition of sugar, significantly increases the processing of Post Grape-Nuts (FPro $=0.9603)$, and the further addition of fats results in an even higher processing score for Post Honey Bunches of Oats with Almonds $($ F Pro $=0.9999)$, showing how FPro ranks the progressive changes in nutrient content. 
medRxiv preprint doi: https://doi.org/10.1101/2021.05.22.21257615; this version posted May 25, 2021. The copyright holder for this preprint (which was not certified by peer review) is the author/funder, who has granted medRxiv a license to display the preprint in perpetuity.

It is made available under a CC-BY-NC-ND 4.0 International license.

a



b

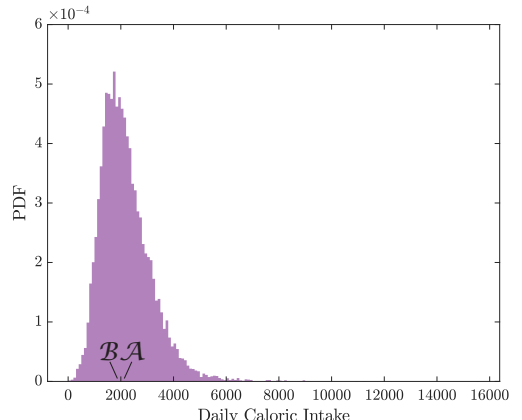

C

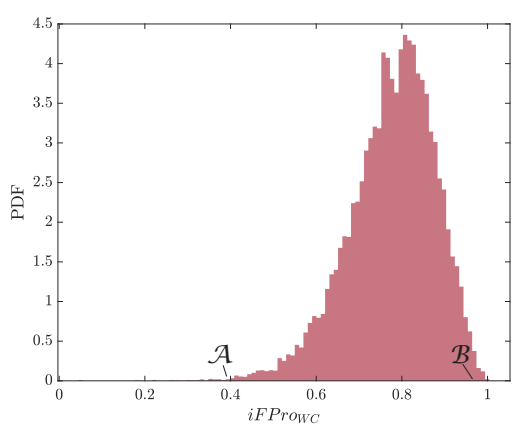

e

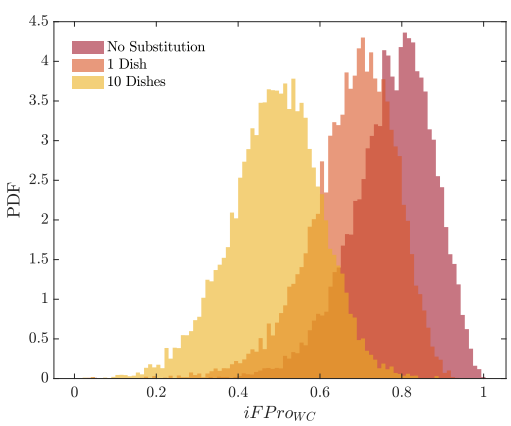

f

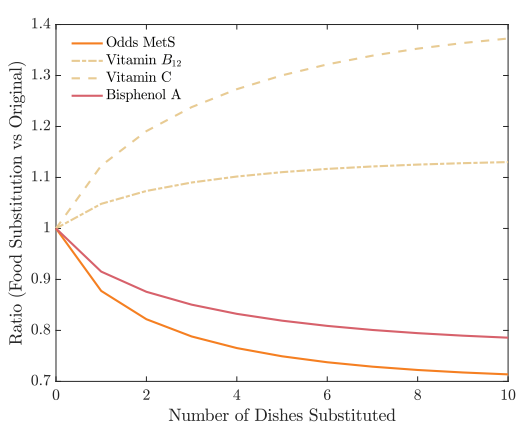

d

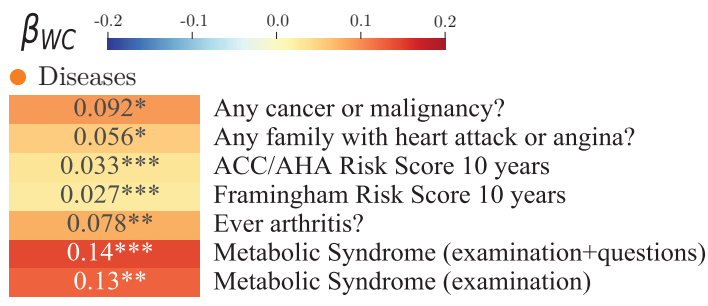

Body Measure

0.028** Subscapular Skinfold (mm)

$0.018^{*} \quad$ Triceps Skinfold $(\mathrm{mm})$

$0.014 * * * \quad$ Total Fat $(\mathrm{g})$

$0.026 * * * \quad$ Trunk Fat (g)

\section{Biochemistry}

\begin{tabular}{cl}
\hline$-0.099 * * *$ & Direct HDL-Cholesterol $(\mathrm{mg} / \mathrm{dL})$ \\
$0.061^{* * *}$ & C-peptide: $\mathrm{SI}(\mathrm{nmol} / \mathrm{L})$ \\
$0.031^{* *}$ & Homocysteine $(\mathrm{umol} / \mathrm{L})$ \\
$0.058^{* * *}$ & Methylmalonic acid $(\mathrm{umol} / \mathrm{L})$ \\
$0.037^{*}$ & Triglycerides $(\mathrm{mg} / \mathrm{dL})$
\end{tabular}

- Nutrients

\begin{tabular}{|cl}
\hline$-0.22 * * *$ & Alpha-carotene $(\mathrm{ug} / \mathrm{dL})$ \\
\hline$-0.11^{* * *}$ & Vitamin B12 $(\mathrm{pg} / \mathrm{mL})$ \\
$-0.18^{* * *}$ & trans-Beta carotene $(\mathrm{ug} / \mathrm{dL})$ \\
$-0.18^{* * *}$ & cis-Beta carotene $(\mathrm{ug} / \mathrm{dL})$ \\
$-0.21^{* * *}$ & b-Cryptoxanthin $(\mathrm{ug} / \mathrm{dL})$ \\
$-0.1 * * *$ & Folate, serum $(\mathrm{ng} / \mathrm{mL})$ \\
$-0.089^{* * *}$ & Retinol(ug/dL) \\
\hline$-0.21^{* * *}$ & Vitamin C $(\mathrm{mg} / \mathrm{dL})$ \\
\hline$-0.085^{* * *}$ & Vitamin D $(\mathrm{ng} / \mathrm{mL})$ \\
$-0.073^{* * *}$ & Vitamin E $(\mathrm{ug} / \mathrm{dL})$ \\
\hline Aging & \\
\hline$-0.073^{* *}$ & Mean Telomere Length \\
\hline
\end{tabular}

- Phytoestrogens

$\begin{array}{cl}0.091^{* * *} & \text { Daidzein }(\mathrm{ng} / \mathrm{mL}) \\ 0.047^{*} & \text { O-Desmethylangolensin }(\mathrm{O}-\mathrm{DMA})(\mathrm{ng} / \mathrm{mL}) \\ -0.061^{* *} & \text { Enterodiol }(\mathrm{ng} / \mathrm{mL}) \\ -0.069^{* *} & \text { Enterolactone }(\mathrm{ng} / \mathrm{mL}) \\ 0.069^{* *} & \text { Genistein }(\mathrm{ng} / \mathrm{mL})\end{array}$

- Acrylamide

$\begin{array}{ll}0.081 * * * & \text { Acrylamide }(\mathrm{pmoL} / \mathrm{G} \mathrm{Hb}) \\ 0.093^{* * *} & \text { Glycideamide }(\mathrm{pmoL} / \mathrm{G} \mathrm{Hb})\end{array}$

- Hydrocarbons

$0.098^{* * *} \quad$ 2-napthol

$0.11 * * * \quad 3$-fluorene (ng/L)

$0.096 * * * \quad 2$-fluorene $(\mathrm{ng} / \mathrm{L})$

$0.082 * * * \quad 1-$ pyrene $(\mathrm{ng} / \mathrm{L})$

Volatile Compounds

\begin{tabular}{|cl}
\hline $0.063^{*}$ & Blood Benzene $(\mathrm{ng} / \mathrm{mL})$ \\
\hline $0.068^{* *}$ & Blood Ethylbenzene $(\mathrm{ng} / \mathrm{mL})$ \\
\hline $0.056^{*}$ & Blood Styrene $(\mathrm{ng} / \mathrm{mL})$ \\
\hline $0.085^{* *}$ & Blood Toluene $(\mathrm{ng} / \mathrm{mL})$
\end{tabular}

- Phthalates

0.079* Mono-2-ethyl-5-carboxypentyl phthalate

$0.1 * * * \quad$ Mono-(2-ethyl-5-hydroxyhexyl) phthalate

$0.1 * * * \quad$ Mono-(2-ethyl-5-oxohexl) phthalate

- Phenols

0.086** Urinary Bisphenol A ( $\mathrm{ng} / \mathrm{mL})$

- Blood Pressure

$0.02 *$ mean systolic

Hormones

$0.058^{* * *}$ Insulin $(\mathrm{uU} / \mathrm{mL})$

Figure 3 
medRxiv preprint doi: https://doi.org/10.1101/2021.05.22.21257615; this version posted May 25, 2021. The copyright holder for this preprint (which was not certified by peer review) is the author/funder, who has granted medRxiv a license to display the preprint in perpetuity.

It is made available under a CC-BY-NC-ND 4.0 International license.

Figure 3: Health implications and Food Substitution. For each of the 20,047 individuals in NHANES (1999-2006), 18+ years old with dietary records [34], we calculated the individual diet processing scores $i F$ Pro $_{W C}$. (a) The average number of unique dishes reported in the dietary interviews, highlighting two individuals $\mathcal{A}$ and $\mathcal{B}$, with comparable number of dishes, 12.5 and 13 reported, respectively. (b) The distribution of average daily caloric intake, showing that individuals $\mathcal{B}$ and $\mathcal{A}$ have similar caloric intake of 1,894 and 2,016 kcal, respectively. (c) The distribution of $i F$ Pro $_{W C}$ for NHANES, indicating that individuals $\mathcal{A}$ and $\mathcal{B}$ display significant differences in $i F$ Pro $_{W C}$, with $\mathcal{B}$ 's diet relying on ultra-processed food $\left(i F\right.$ Pro $_{W C}=$ 0.9572), and $\mathcal{A}$ reporting simple recipes $\left(i F\right.$ Pro $\left._{W C}=0.3981\right)$ (Figure S6). (d) We measured the association of various phenotypes with $i F$ Pro $_{W C}$, correcting for age, gender, ethnicity, socio-economic status, BMI, and caloric intake (SI Section 4). We report the standardized $\beta$ coefficient, quantifying the effect on each exposure when the Box-Cox transformed dietary scores increase of one standard deviation over the population. For continuous exposures the coefficients are fully standardized, while for logistic regression (disease phenotypes) we opted for partially standardized coefficients to help interpretability (SI Section 4). Each variable is color-coded according to $\beta$, positive associations shown in red, and negative associations in blue. (e) Changes in $i F$ Pro $_{W C}$ when one (orange) or up to ten (yellow) dishes are substituted with their less processed versions, following the prioritization rule defined in Eq. S5. (f) The impact of substituting different number of dishes on the odds of metabolic syndrome, concentrations of vitamin $B_{12}$, vitamin $\mathrm{C}$, and bisphenol $\mathrm{A}$, showing that a minimal substitution strategy can significantly alter the health implications of ultra-processed food. 
medRxiv preprint doi: https://doi.org/10.1101/2021.05.22.21257615; this version posted May 25, 2021. The copyright holder for this preprint (which was not certified by peer review) is the author/funder, who has granted medRxiv a license to display the preprint in perpetuity.

It is made available under a CC-BY-NC-ND 4.0 International license.

SUPPLEMENTARY INFORMATION

\section{Contents}

\begin{tabular}{|lll}
\hline 1 & Training Dataset & 2
\end{tabular}

1.1 Food Composition Databases . . . . . . . . . . . . . . . . . . . . . . . 2

1.2 FNDDS 2009-2010 . . . . . . . . . . . . . . . . . . . . . . . . . . . . 3

1.3 NOVA Manual Classification Coverage . . . . . . . . . . . . . . . . . . . . . . . . 5

1.4 Nutrient Panels . . . . . . . . . . . . . . . . . . . . . . . . . . . . 5

2 Random Forest Classifier FoodProX and Food Processing Score FPro 8

2.1 Random Forest Classifier . . . . . . . . . . . . . . . . . . . . . . . . . . . . . . . 8

2.2 Food Processing Score FPro . . . . . . . . . . . . . . . . . . . . . . . . . . . . . 9

2.3 Validation of FPro in Different FNDDS Editions . . . . . . . . . . . . . . . . . . 10

3 Individual Diet Processing Scores iFPro and Exposome 11

3.1 Individual Processing Score $i F$ Pro . . . . . . . . . . . . . . . . . . . . . . . . . . 11

3.2 Population Characteristics . . . . . . . . . . . . . . . . . . . . . . . . 11

3.3 Correlation between $i$ Pro $_{W G}, i F$ Pro $_{W C}$, and HEI-15. . . . . . . . . . . . . . . . 12

3.4 Water Consumption in NHANES . . . . . . . . . . . . . . . . . . . . . . . . . . . 13

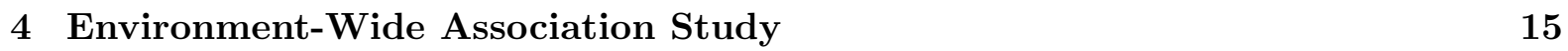

$\begin{array}{lll}5 \text { Food Substitution } & 23\end{array}$ 
medRxiv preprint doi: https://doi.org/10.1101/2021.05.22.21257615; this version posted May 25, 2021. The copyright holder for this preprint (which was not certified by peer review) is the author/funder, who has granted medRxiv a license to display the preprint in perpetuity.

\section{Training Dataset}

\subsection{Food Composition Databases}

The food supply, representing the full inventory of all foods available for human consumption, along with their nutritional content, plays an important role in determining an individual's nutrient exposure. Nutritional information is captured by food databases, collections of nutrient measurements for extensive samples of the food supply. Here we define as nutrients all chemicals catalogued by food databases, whether they refer to unique chemicals, like vitamin $\mathrm{C}$, or aggregate measures, like total fat or total sugar. Additionally, all major nutrient databases include calories, measuring how much energy our body could get from eating or drinking the selected product. Which foods and which nutrients to report is strictly dependent on the database considered. For instance, USDA SR Legacy, the authoritative source of food composition data in the United States contains 7,793 food items with variable nutrient resolution, from a minimum of 8 nutrients, up to 138 (Figure S1) [2]. In comparison, USDA FNDDS, designed for the epidemiological analysis of dietary intake data collected by the National Health and Nutrition Examination Survey (NHANES), reports 65 to 102 nutrients for all foods, depending on the edition, containing no missing nutrient values (Figure S1] [3, 4].

The nutrient resolution available to consumers is significantly lower: the Food and Drug Administration (FDA) mandates the listing of 14 nutrients on the nutrition facts label, from saturated and trans fat, to sodium and vitamin $\mathrm{C}$ [1] An updated nutrition facts label was finalized in 2016, removing vitamin A and C, but listing added sugars, vitamin D, and potassium. However, the compliance deadline for certain food categories was extended to July 2021, and for the majority of the data describing branded products, we observed a significantly higher coverage of the nutrition facts prior to 2016.

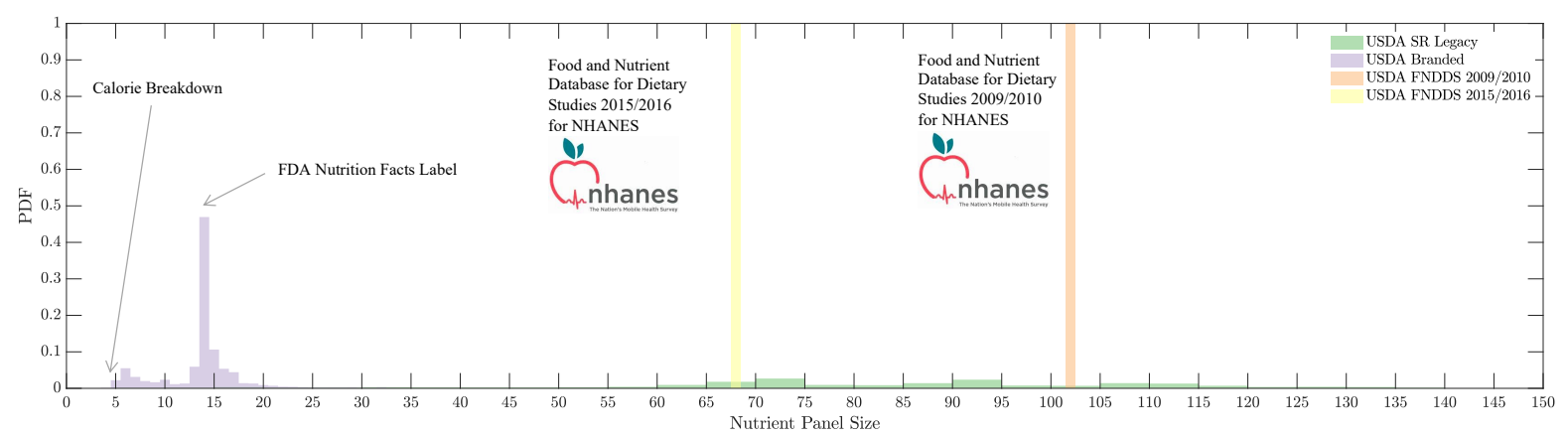

Figure SI. 1: Nutrient Panel Resolution for Different Food Databases. To fully capture the nutrient alterations caused by food processing, we need access to the nutrient information characterizing each food in the food supply. The resolution available for branded products sold in grocery stores is very limited, frequently less than what required by FDA nutrition facts $[1]$. 
medRxiv preprint doi: https://doi.org/10.1101/2021.05.22.21257615; this version posted May 25, 2021. The copyright holder for this preprint (which was not certified by peer review) is the author/funder, who has granted medRxiv a license to display the preprint in perpetuity.

It is made available under a CC-BY-NC-ND 4.0 International license.

\section{$1.2 \quad$ FNDDS 2009-2010}

The Food and Nutrient Database for Dietary Studies (FNDDS) is designed by the USDA to provide food composition data (e.g. the amount of Vitamin $\mathrm{C}$ per $100 \mathrm{~g}$ of a selected ingredient) for foods and beverages reported in the dietary component of the National Health and Nutrition Examination Survey (NHANES), a biannual cross-sectional survey of the US Population conducted by Center for Disease Control and Prevention (CDC) to monitor the health of Americans. FNDDS is derived by combining the food items provided in the USDA National Nutrient Database for Standard Reference (SR). In other words, each item in FNDDS is related to one or more foods in SR, reported as ingredients in FNDDS. Differently from SR, designed for the dissemination of food composition data, FNDDS's goal is to enable the analysis of dietary intake, containing no missing nutrient values [5]. Since 2017, the USDA has been harmonizing these different data sources in FoodData Central (FDC) [6].

As shown in Figure \$1, for the years 2007-2010 the USDA developed a flavonoids database for population surveys that extended the original nutritional panel of 65 nutrients to 102. For our analysis we kept all nutrients measured in g, mg or $\mu g$, dropping "Energy", "Folate, DFE" and "Vitamin A, RAE", resulting in 99 nutrients, converted to grams (g).

A

Manually Classified Food Items $(\# 2,484)$

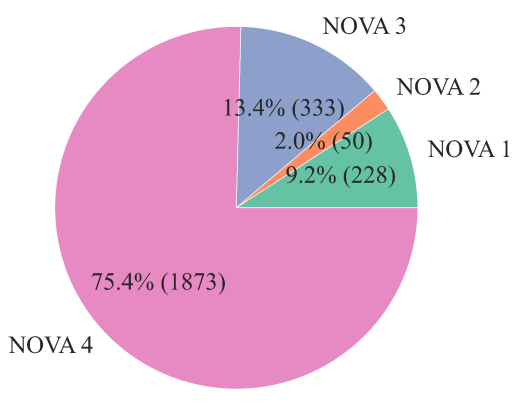

B

Addition of Single-Ingredient Food Items (\#478)

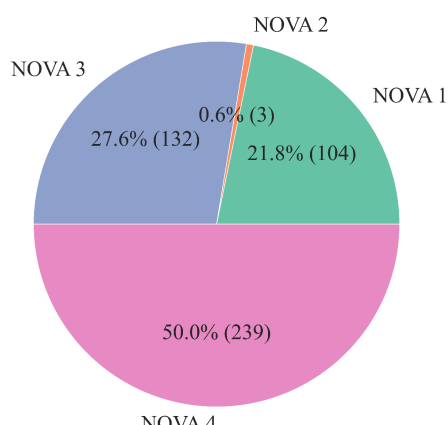

C

Training Dataset $(\# 2,971)$

NOVA 3

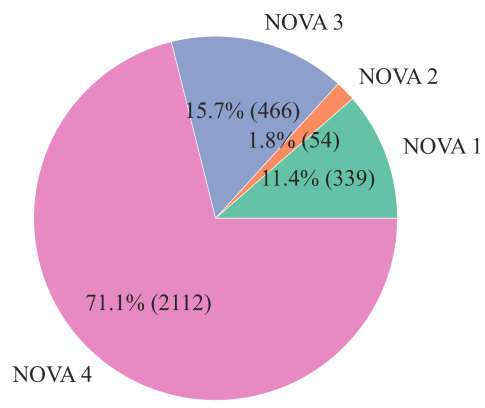

Figure SI. 2: Proportion of NOVA Classes in the Manual Classification and Training Dataset. (A) Steele et al. 7] manually assigned NOVA classes to 2,484 from 7,253 food items in FNDDS 2009-2010, (B) We identified 478 single-ingredient and unclassified food items in FNDDS 2009-2010 linked to a single food in the SR database with assigned NOVA labels. (C) Final training dataset with the corrections on single-ingredient food items and the addition of 9 manually classified food items reported in Table $: 1$ 
medRxiv preprint doi: https://doi.org/10.1101/2021.05.22.21257615; this version posted May 25, 2021. The copyright holder for this preprint (which was not certified by peer review) is the author/funder, who has granted medRxiv a license to display the preprint in perpetuity.

It is made available under a CC-BY-NC-ND 4.0 International license .

We chose FNDDS 2009-2010 as data training for FoodProX, as it gave us the possibility to combine the manual labels assigned by Steele et al. in [7], with the widest panel of nutrients available for population studies. Out of 7,253 foods in FNDDS 2009-2010, 2,484 food items are assigned to a unique NOVA class, while the remaining 4,769 foods are not classified, or need further decomposition in 2,946 ingredients imported from the SR24 database.

Figure 52 A shows the proportion of NOVA classes in the initial dataset, labels mainly derived by following the hierarchical encoding of food items provided by FNDDS. Indeed, each food is assigned to an 8-digit code, and the first five digits represent food categories. For instance, code 13230120 is assigned to "Pudding, flavors other than chocolate, ready-to-eat, sugar free" where the first digit ' 1 ' represents "Milk and Milk Products"; the first two digits '13' represents "Milk Desserts and Sauce"; and similarly '132' represents "Puddings, Custards, and other Milk Desserts." Relying on FNDDS food categories leads to two major limitations of the current classification system: (a) the existence of many exceptions. For example, a non ultra-processed food could belong to a category assumed to contain only ultra-processed food. Resolving these exceptions is a laborious work that requires domain knowledge; (b) limited scalability, as not all databases have a fine-tuned hierarchy of categories assigned to foods comparable to FNDDS.

Additionally, we found that some unclassified items, despite being labeled as requiring further decomposition, had only one ingredient. For instance, this is the case for the unclassified item 'Egg, whole, raw' (food code 31101010), created by linking only a single food from the SR database: 'Egg, whole, raw, fresh' (SR code 1123). Hence, we migrated 478 such unclassified single-ingredient foods to the training dataset (Figure $\mathrm{S} 2 \mathrm{~B}$ ).

To further improve the training dataset, we manually classified nine foods, to extend the coverage of staple ingredients like 'Salt', or poorly represented classes like meat and fish (Table S1). In particular, the addition of 'Salt' in the training helped FoodProX to better calibrate the sodium relevance in identifying ultra-processed food.

Table SI. 1: Manual Addition to the Training Dataset

\begin{tabular}{|l|r|}
\hline Food Description & NOVA Class \\
\hline Salt & 2 \\
\hline Fish, NS as to type, raw & 1 \\
\hline Flounder, raw & 1 \\
\hline Herring, raw & 1 \\
\hline Mackerel, raw & 1 \\
\hline Ocean perch, raw & 1 \\
\hline Mussels, raw & 1 \\
\hline Grapes, American type, slip skin, raw & 1 \\
\hline Steak tartare (raw ground beef and egg) & 3 \\
\hline
\end{tabular}


medRxiv preprint doi: https://doi.org/10.1101/2021.05.22.21257615; this version posted May 25, 2021. The copyright holder for this preprint (which was not certified by peer review) is the author/funder, who has granted medRxiv a license to display the preprint in perpetuity.

It is made available under a CC-BY-NC-ND 4.0 International license.

\subsection{NOVA Manual Classification Coverage}

The coverage of NOVA classification for FNDDS 2001-2017 is presented by Figure $\$ 3$ For over $55 \%$ of the databases, NOVA classification relies on having a precise ingredient decomposition of food items, an information that is extremely uncommon. To note, the manual NOVA classification has been updated since the initial classification on FNDDS 2009-2010 used in [7]. For clarity, only for FNDDS 2009-2010 in Figure \$3, we used the NOVA classification conducted by Steele et al. in [7, which is the data-source that we used to train FoodProX. However, close to the convergence of this manuscript, Steele and colleagues have updated the manual classification for FNDDS 2009-2010, and propagated the labels in different cohorts by matching the food codes through the years. In the updated manual classification of FNDDS 2009-2010 the percentage of food items relying on ingredient decomposition is increased to $58.98 \%$ from $55.69 \%$.

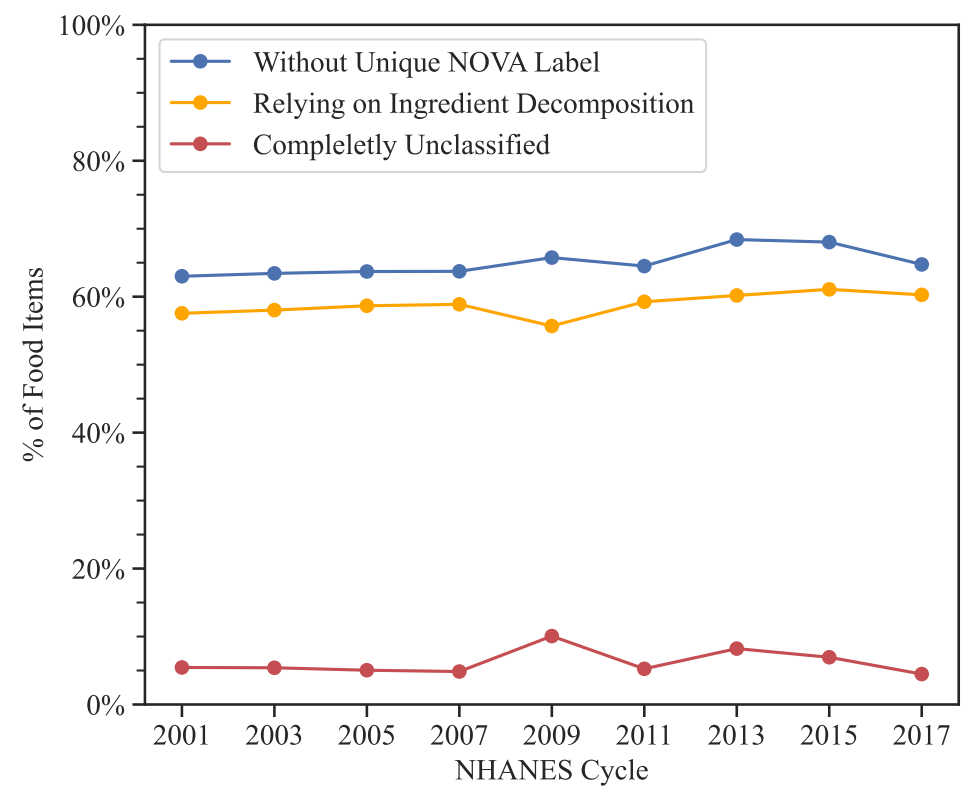

Figure SI. 3: Manual NOVA Classification Coverage Over FNDDS 2001-2017. On average $35 \%$ of the food items have a manual NOVA label without relying on ingredient decomposition.

\subsection{Nutrient Panels}

The large nutritional panel available for FNDDS 2009-2010 allowed us to train FoodProX with varying subsets of nutrients. The widest panel consists of 99 nutrients, including the flavonoid measurements developed for NHANES 2007-2010 (Table S2] 8]. Among these 99 nutrients, we further selected and trained on 62 nutrients common to NHANES 2001-2018 (Table S3), and 58 nutrients available in NHANES 1999-2018 (Table \$4). Figures 1A-1C in manuscript describe the results on FNDDS 2009-2010, with 99 nutrients, while Figures 1D-1E 
medRxiv preprint doi: https://doi.org/10.1101/2021.05.22.21257615; this version posted May 25, 2021. The copyright holder for this preprint (which was not certified by peer review) is the author/funder, who has granted medRxiv a license to display the preprint in perpetuity.

It is made available under a CC-BY-NC-ND 4.0 International license

are related to the analysis of FNDDS 2015-2016, therefore using a nutrient panel of 62 nutrients. For the epidemiological analysis in Section 3, leveraging data from 1999 to 2006, we opted for 58 nutrients.

With the goal to tackle branded products and the consumer space, we additionally trained on a subset of 12 nutrients contributing to FDA nutrition facts (Table \$5), excluding calories and total amount of trans fatty acids, as the latter is not available in the original batch of 99 nutrients.

All nutrients were log-transformed and 0 values were substituted with $e^{-20}$, choice justified by the order of magnitudes spanned by nutrient concentrations in food $[9]$.

Table SI. 2: 99 Nutrient Panel for NHANES 2007-2010

\begin{tabular}{|c|c|c|c|c|}
\hline \multicolumn{3}{|c|}{ Nutrients } & \multicolumn{2}{|c|}{37 Additional Nutrients From FNDDS Flavoniod 2007-2010 Database } \\
\hline Protein & Vitamin E (alpha-tocopherol) & $6: 0$ & Total flavonoids & Eriodictyol \\
\hline Total Fat & Vitamin D (D2 + D3) & $8: 0$ & Cyanidin & Hesperetin \\
\hline Carbohydrate & Cryptoxanthin, beta & 10:0 & Petunidin & Naringenin \\
\hline Alcohol & Lycopene & $12: 0$ & Delphinidin & Total flavanones \\
\hline Water & Lutein + zeaxanthin & $14: 0$ & Malvidin & Apigenin \\
\hline Caffeine & Vitamin C & $16: 0$ & Pelargonidin & Luteolin \\
\hline Theobromine & Thiamin & $18: 0$ & Peonidin & Total flavones \\
\hline Sugars, total & Riboflavin & $18: 1$ & Total anthocyanidins & Isorhamnetin \\
\hline Fiber, total dietary & Niacin & $18: 2$ & $(+)$-Catechin & Kaempferol \\
\hline Calcium & Vitamin B-6 & $18: 3$ & (-)-Epigallocatechin & Myricetin \\
\hline Iron & Folate, total & $20: 4$ & (-)-Epicatechin & Quercetin \\
\hline Magnesium & Vitamin B-12 & $22: 6 n-3$ & (-)-Epicatechin 3-gallate & Total flavonols \\
\hline Phosphorus & Choline, total & $16: 1$ & (-)-Epigallocatechin 3-gallate & Daidzein \\
\hline Potassium & Vitamin K (phylloquinone) & 18:4 & Theaflavin & Genistein \\
\hline Sodium & Folic acid & $20: 1$ & Thearubigins & Glycitein \\
\hline Zinc & Folate, food & $20: 5 n-3$ & Theaflavin-3,3'-digallate & Total isoflavones \\
\hline Copper & Vitamin $\mathrm{E}$, added & $22: 1$ & Theaflavin-3'-gallate & \\
\hline Selenium & Vitamin B-12, added & $22: 5 n-3$ & Theaflavin-3-gallate & \\
\hline Retinol & Cholesterol & Fatty acids, total monounsaturated & (+)-Gallocatechin & \\
\hline Carotene, beta & Fatty acids, total saturated & Fatty acids, total polyunsaturated & Total catechins (monomeric flavan-3-ols only) & \\
\hline Carotene, alpha & 4:0 & & Total flavan-3-ols & \\
\hline
\end{tabular}


medRxiv preprint doi: https://doi.org/10.1101/2021.05.22.21257615; this version posted May 25, 2021. The copyright holder for this preprint (which was not certified by peer review) is the author/funder, who has granted medRxiv a license to display the preprint in perpetuity.

It is made available under a CC-BY-NC-ND 4.0 International license .

Table SI. 3: 62 Nutrient Panel for NHANES 2001-2018 Cycles

\begin{tabular}{|l|l|l|}
\hline \multicolumn{3}{|c|}{ Nutrients } \\
\hline Protein & Vitamin E (alpha-tocopherol) & $6: 0$ \\
\hline Total Fat & Vitamin D (D2 + D3) & $8: 0$ \\
\hline Carbohydrate & Cryptoxanthin, beta & $10: 0$ \\
\hline Alcohol & Lycopene & $12: 0$ \\
\hline Water & Lutein + zeaxanthin & $14: 0$ \\
\hline Caffeine & Vitamin C & $16: 0$ \\
\hline Theobromine & Thiamin & $18: 0$ \\
\hline Sugars, total & Riboflavin & $18: 1$ \\
\hline Fiber, total dietary & Niacin & $18: 2$ \\
\hline Calcium & Vitamin B-6 & $18: 3$ \\
\hline Iron & Folate, total & $20: 4$ \\
\hline Magnesium & Vitamin B-12 & $22: 6 \mathrm{n}-3$ \\
\hline Phosphorus & Choline, total & $16: 1$ \\
\hline Potassium & Vitamin K (phylloquinone) & $18: 4$ \\
\hline Sodium & Folic acid & $20: 1$ \\
\hline Zinc & Folate, food & $20: 5 \mathrm{n}-3$ \\
\hline Copper & Vitamin E, added & $22: 1$ \\
\hline Selenium & Vitamin B-12, added & $22: 5 \mathrm{n}-3$ \\
\hline Retinol & Cholesterol & Fatty acids, total monounsaturated \\
\hline Carotene, beta & Fatty acids, total saturated & Fatty acids, total polyunsaturated \\
\hline Carotene, alpha & $4: 0$ & \\
\hline
\end{tabular}

Table SI. 4: 58 Nutrient Panel for NHANES 1999-2018 Cycles

\begin{tabular}{|l|l|l|}
\hline \multicolumn{3}{|c|}{ Nutrients } \\
\hline Protein & Vitamin E (alpha-tocopherol) & $14: 0$ \\
\hline Total Fat & Cryptoxanthin, beta & $16: 0$ \\
\hline Carbohydrate & Lycopene & $18: 0$ \\
\hline Alcohol & Lutein + zeaxanthin & $18: 1$ \\
\hline Water & Vitamin C & $18: 2$ \\
\hline Caffeine & Thiamin & $18: 3$ \\
\hline Theobromine & Riboflavin & $20: 4$ \\
\hline Sugars, total & Niacin & $22: 6 \mathrm{n}-3$ \\
\hline Fiber, total dietary & Vitamin B-6 & $16: 1$ \\
\hline Calcium & Folate, total & $18: 4$ \\
\hline Iron & Vitamin B-12 & $20: 1$ \\
\hline Magnesium & Vitamin K (phylloquinone) & $20: 5 \mathrm{n}-3$ \\
\hline Phosphorus & Folic acid & $22: 1$ \\
\hline Potassium & Folate, food & $22: 5 \mathrm{n}-3$ \\
\hline Sodium & Cholesterol & Fatty acids, total monounsaturated \\
\hline Zinc & Fatty acids, total saturated & Fatty acids, total polyunsaturated \\
\hline Copper & $4: 0$ & \\
\hline Selenium & $6: 0$ & \\
\hline Retinol & $8: 0$ & \\
\hline Carotene, beta & $10: 0$ & \\
\hline Carotene, alpha & $12: 0$ & \\
\hline
\end{tabular}


medRxiv preprint doi: https://doi.org/10.1101/2021.05.22.21257615; this version posted May 25, 2021. The copyright holder for this preprint (which was not certified by peer review) is the author/funder, who has granted medRxiv a license to display the preprint in perpetuity.

It is made available under a CC-BY-NC-ND 4.0 International license .

Table SI. 5: 12 Nutrient Panel for Branded Products

\begin{tabular}{|l|}
\hline \multicolumn{1}{|c|}{ Nutrients } \\
\hline Protein \\
\hline Total Fat \\
\hline Carbohydrate \\
\hline Sugars, total \\
\hline Fiber, total dietary \\
\hline Calcium \\
\hline Iron \\
\hline Sodium \\
\hline Vitamin C \\
\hline Cholesterol \\
\hline Fatty acids, total saturated \\
\hline Total Vitamin A = Retinol + Carotene, beta + Carotene, alpha + Cryptoxanthin, beta \\
\hline
\end{tabular}

\section{Random Forest Classifier FoodProX and Food Processing Score F Pro}

\subsection{Random Forest Classifier}

We evaluated the performance and stability of FoodProX over a 5 -fold stratified cross validation of the labeled dataset (Figure $\mathrm{S} 7 \mathrm{C}$ ), with varying input resolution. In Figures $\mathrm{S} 7 \mathrm{~A}-\mathrm{H}$ we show the ROC curves and Precision-Recall curves for each NOVA class, while in Tables : $64 \mathrm{~A}$ and $\mathrm{s} 6 \mathrm{~B}$ we report average and standard deviation of AUC and AUP over the 5 folds, and across the different nutrient panels, as reported in the manuscript. The high performance for different nutrient resolutions is encouraging, as for many foods we lack access to an extensive panel of nutrients.

To improve the performance of the classifier on new data and limit over-fitting, we retrained it using SMOTE [10] to correct for the unbalance in class representation, and created and ensemble voting system of 5 classifiers trained on $4 / 5$ of the generated data. The predictions on unseen data are then calculated as the average of the 5 classifiers.

Table SI. 6: AUC and AUP for the four NOVA classes. For each NOVA class we report average and standard deviation of AUC and AUP over the stratified 5-folds, for 12, 62, and 99 input nutrients. We summarize the results across nutrient panels of different resolution in bold.

(A)

\begin{tabular}{|c|c|c|c|c|}
\hline & NOVA 1 & NOVA 2 & NOVA 3 & NOVA 4 \\
\hline Average AUC Nutrition Facts & 0.981662 & 0.966348 & 0.967094 & 0.976772 \\
\hline Std AUC Nutrition Facts & 0.003621 & 0.044898 & 0.010411 & 0.003432 \\
\hline Average AUC 62 Nutrients & 0.980837 & 0.962878 & 0.970605 & 0.979866 \\
\hline Std AUC 62 Nutrients & 0.00173 & 0.048586 & 0.00806 & 0.004876 \\
\hline Average AUC 99 Nutrients & 0.978806 & 0.960406 & 0.971156 & 0.980085 \\
\hline Std AUC 99 Nutrients & 0.002772 & 0.052151 & 0.007394 & 0.004237 \\
\hline Average AUC & 0.980435 & 0.963211 & 0.969618 & 0.978908 \\
\hline Std AUC & 0.0012 & 0.002437 & 0.001799 & 0.001513 \\
\hline
\end{tabular}

(B)

\begin{tabular}{|c|c|c|c|c|}
\hline & NOVA 1 & NOVA 2 & NOVA 3 & NOVA 4 \\
\hline Average AUP Nutrition Facts & 0.891112 & 0.756997 & 0.864605 & 0.990558 \\
\hline Std AUP Nutrition Facts & 0.035105 & 0.169225 & 0.040566 & 0.001414 \\
\hline Average AUP 62 Nutrients & 0.891971 & 0.736245 & 0.873025 & 0.991702 \\
\hline Std AUP 62 Nutrients & 0.024412 & 0.185744 & 0.03922 & 0.002178 \\
\hline Average AUP 99 Nutrients & 0.881419 & 0.74707 & 0.879123 & 0.991783 \\
\hline Std AUP 99 Nutrients & 0.024092 & 0.193387 & 0.032601 & 0.001954 \\
\hline Average AUP & 0.888168 & 0.74677 & 0.872251 & 0.991348 \\
\hline Std AUP & 0.004785 & 0.008475 & 0.005952 & 0.00056 \\
\hline
\end{tabular}


medRxiv preprint doi: https://doi.org/10.1101/2021.05.22.21257615; this version posted May 25,2021 . The copyright holder for this preprint (which was not certified by peer review) is the author/funder, who has granted medRxiv a license to display the preprint in perpetuity.

It is made available under a CC-BY-NC-ND 4.0 International license .
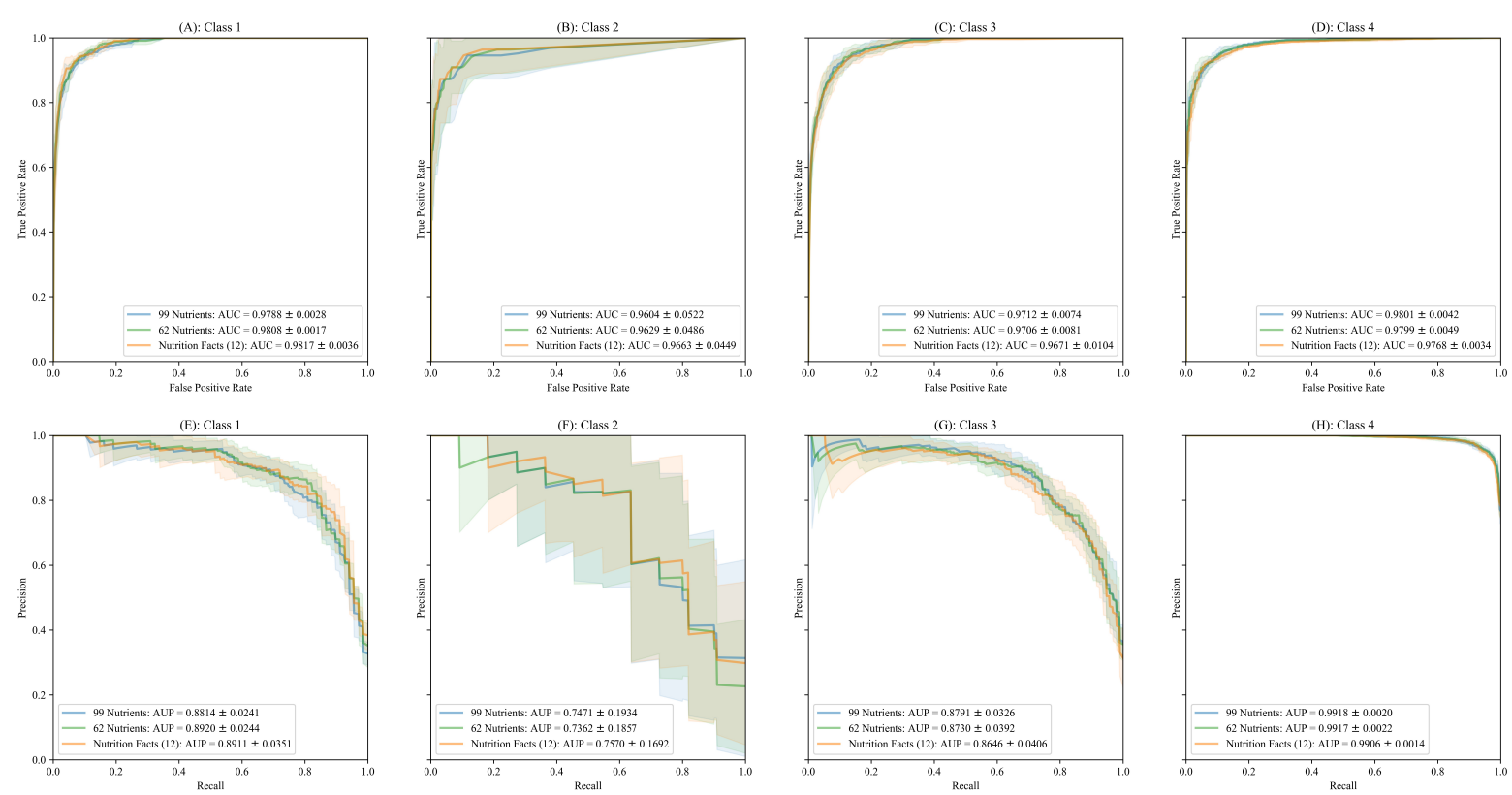

Figure SI. 4: Random Forest performance over the 4 NOVA classes. For each NOVA class we evaluated the performance of the random forest classifier with a 5 -fold cross validation. We observe similar performances for the classifiers trained with 99, 62 and 12 nutrients. In Panels A-D we show the ROC curves for each NOVA class, while panels E-F display the Precision-Recall curves.

\subsection{Food Processing Score F Pro}

The classifier probability space is a 4-D probability simplex that collects all vectors satisfying

$$
\left\{\vec{p} \in \mathbb{R}^{4}, p_{1}+p_{2}+p_{3}+p_{4}=1, \quad p_{i} \geq 0 \forall i\right\}
$$

We define the processing score $F$ Pro $_{k}$ as the projection of any food $\vec{p}_{k}=\left(p_{1}^{k}, p_{2}^{k}, p_{3}^{k}, p_{4}^{k}\right)$ over the line going from the pure minimally-processed state $\vec{p}_{M P}=(1,0,0,0)$ to the pure ultraprocessed state $\vec{p}_{U P}=(0,0,0,1)$, represented by the parametric equation

$$
\overrightarrow{l(t)}=\left[\begin{array}{l}
1 \\
0 \\
0 \\
0
\end{array}\right]+t\left[\begin{array}{c}
-1 \\
0 \\
0 \\
1
\end{array}\right] \text {, }
$$

equivalent to the explicit equation $p_{1}=1-p_{4}$. The orthogonal projection of food $\vec{p}_{k}$ follows as the intersection between Eq. $\$ 2$ and the plane passing through $\vec{p}_{k}$ and orthogonal to $\overrightarrow{l(t)}$, i.e.

$$
-p_{1}+p_{4}+p_{1}^{k}-p_{4}^{k}=0
$$


medRxiv preprint doi: https://doi.org/10.1101/2021.05.22.21257615; this version posted May 25, 2021. The copyright holder for this preprint (which was not certified by peer review) is the author/funder, who has granted medRxiv a license to display the preprint in perpetuity.

It is made available under a CC-BY-NC-ND 4.0 International license .

The parameter $t^{*}$ satisfying Eqs. 52 -s 3 determines the processing score $F$ Pro $_{k}$ in Eq. 1.

Of note, FPro assigns a value around 0.5 for all NOVA $2 / 3$ classes, which are then differentiated using the $p_{2} / p_{3}$ ratio.

\subsection{Validation of F Pro in Different FNDDS Editions}

We investigated the relation of FPro, trained on FNDDS 2009-2010 with a 62 nutrient panel, and NOVA manual classification in other editions of FNDDS, to control for any potential over-fitting and validate the performance of our algorithm on new foods, or foods whose nutrient content has changed over time. In particular, in Figure $\$ 5$ we show the results for FNDDS 20152016, so far, the USDA database for dietary studies with the highest number of food items. All the four classes of manually labeled items correspond to well localized and distinguishable distributions of FPro.

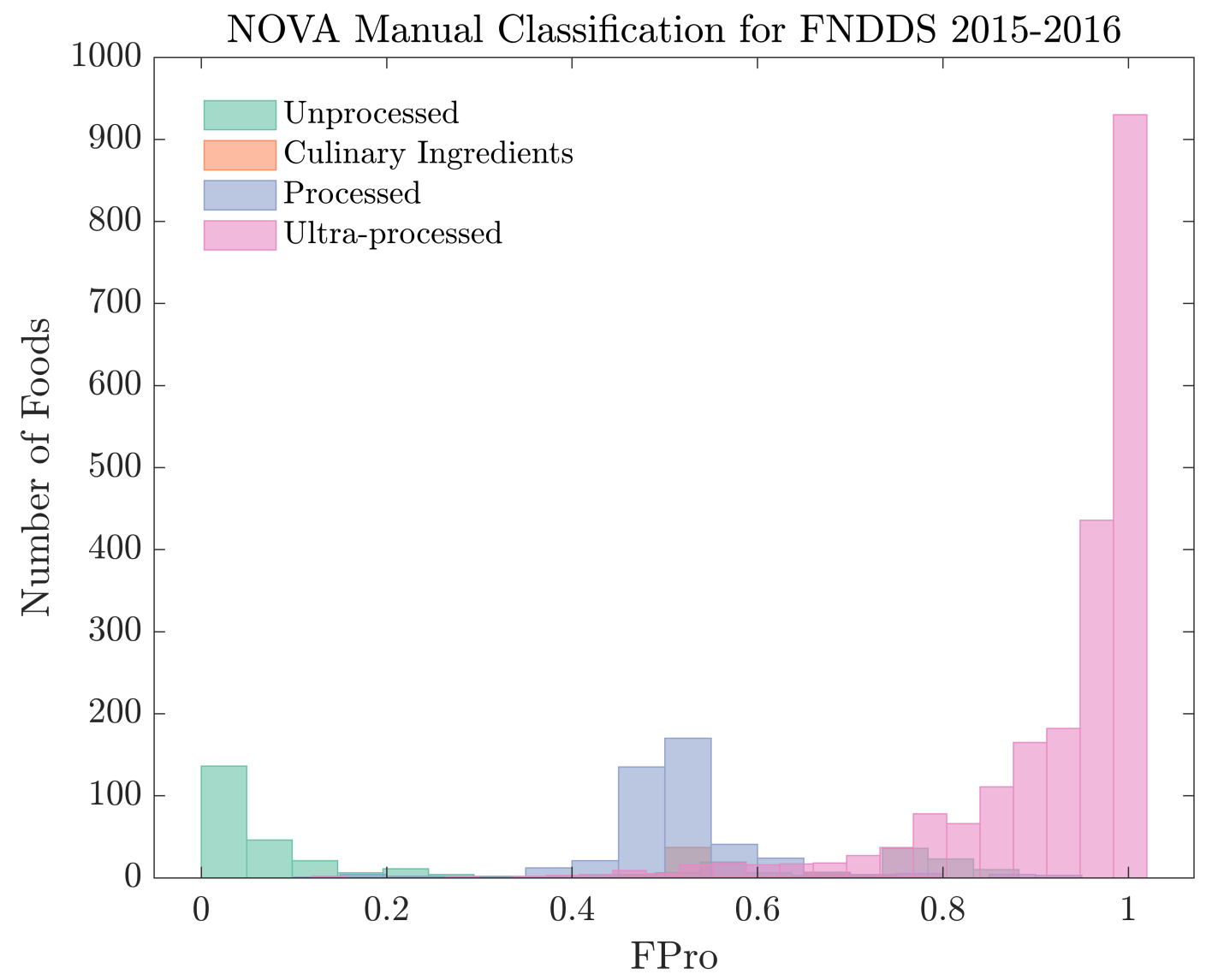

Figure SI. 5: Food Processing Score for NOVA Manual Labels in 2015-2016. Variability of FPro (trained on FNDDS 2009-2010) within manual NOVA classes for FNDDS 2015-2016. 
medRxiv preprint doi: https://doi.org/10.1101/2021.05.22.21257615; this version posted May 25, 2021. The copyright holder for this preprint (which was not certified by peer review) is the author/funder, who has granted medRxiv a license to display the preprint in perpetuity.

It is made available under a CC-BY-NC-ND 4.0 International license .

\section{Individual Diet Processing Scores iF Pro and Exposome}

\subsection{Individual Processing Score iF Pro}

To capture the extent of processing in individuals' diet we focus on two weighting schemes: a calorie-based score (Eq. 2), and a gram-based score,

$$
i \operatorname{Pro}_{W G}^{j}=\sum_{k}^{D_{j}} \frac{w_{k}^{j}}{W^{j}} \text { Pro }_{k}
$$

where $D_{j}$ is the number of dishes consumed by individual $j, W^{j}$ is her total amount of food in grams, and $w_{k}^{j}$ is the amount of grams consumed for each food item (excluding water consumption, see Section $\mathrm{S} 3.4$.

\subsection{Population Characteristics}

NHANES captures a variety of information ranging from demographic and dietary intake, to lab and physical examinations. This wealth of information is compiled into hundreds of publicly available data files, that altogether provide over 1,000 variables.

To investigate the relation between iF Pro and health, we focused on NHANES 1999-2006 exposome and phenome database, a harmonized dataset created by Patel et al. in [11], merging 255 data files from four cycles of NHANES, for a total of 41,474 individuals and 1,191 variables. The summary statistics for $i F$ Pro $_{W C}$ and $i F$ Pro $_{W G}$, characterizing the 20,047 adults $(18+)$ in the cohort, are presented in Tables $\mathrm{S} 7$ and $\mathrm{S} 8$, All predictions are calculated with the 58 nutrient panel in Table $\mathrm{S} 4$. For all individuals who completed two-day dietary recalls (in-person and phone interview) we calculated a daily average $i F$ Pro, while for the remaining participants we used just the data from in-person interview. The relevance of each individual for population statistics is based on survey weights 12,13 . 
medRxiv preprint doi: https://doi.org/10.1101/2021.05.22.21257615; this version posted May 25, 2021. The copyright holder for this preprint (which was not certified by peer review) is the author/funder, who has granted medRxiv a license to display the preprint in perpetuity.

It is made available under a CC-BY-NC-ND 4.0 International license .

Table SI. 7: Population characteristics for $i F$ Pro $_{W C}$

\begin{tabular}{|c|c|c|c|c|c|c|}
\hline & \multirow{2}{*}{ mean } & \multicolumn{5}{|c|}{${ }_{i F P r o}^{W C}$} \\
\hline & & $0.0-0.2$ & $0.2-0.4$ & $0.4-0.6$ & $0.6-0.8$ & $0.8-1.0$ \\
\hline Counts Subjects $(n=20,046)$ & & 4 & 63 & 1487 & 11180 & 7313 \\
\hline Age - mean $\pm S E$ & $45.28 \pm 0.3$ & $58.01 \pm 6.16$ & $47.2 \pm 3.06$ & $51.4 \pm 0.64$ & $47.36 \pm 0.37$ & $41.3 \pm 0.3$ \\
\hline Poverty Income Ratio - mean \pm SE & $2.99 \pm 0.04$ & $2.58 \pm 0.98$ & $2.92 \pm 0.3$ & $2.97 \pm 0.07$ & $3.06 \pm 0.04$ & $2.88 \pm 0.05$ \\
\hline Calories Consumed - mean \pm SE & $2189.13 \pm 10.36$ & $534.25 \pm 162.24$ & $1359.03 \pm 184.71$ & $1772.85 \pm 29.81$ & $2143.11 \pm 13.16$ & $2329.7 \pm 15.07$ \\
\hline $\mathrm{BMI}-$ mean $\pm \mathrm{SE}$ & $28.13 \pm 0.1$ & $26.48 \pm 1.63$ & $29.33 \pm 1.33$ & $27.45 \pm 0.28$ & $27.92 \pm 0.1$ & $28.53 \pm 0.13$ \\
\hline female - count (\%) & & $4(1)$ & $41(0.65)$ & $879(0.59)$ & $5798(0.52)$ & $3763(0.51)$ \\
\hline white - count (\%) & & $0(0)$ & $20(0.32)$ & $663(0.45)$ & $5389(0.48)$ & $3525(0.48)$ \\
\hline black - count (\%) & & $0(0)$ & $21(0.33)$ & $227(0.15)$ & $2160(0.19)$ & $1810(0.25)$ \\
\hline mexican - count (\%) & & $2(0.5)$ & $15(0.24)$ & $443(0.3)$ & $2737(0.24)$ & $1460(0.2)$ \\
\hline other hispanic - count (\%) & & $0(0)$ & $6(0.1)$ & $86(0.06)$ & $467(0.04)$ & $270(0.04)$ \\
\hline
\end{tabular}

Table SI. 8: Population characteristics for $i F \operatorname{Pro}_{W G}$

\begin{tabular}{|c|c|c|c|c|c|c|}
\hline & \multirow{2}{*}{ mean } & \multicolumn{5}{|c|}{${ }{ }_{F P r o}{ }_{W G}$} \\
\hline & & $0.0-0.2$ & $0.2-0.4$ & $0.4-0.6$ & $0.6-0.8$ & $0.8-1.0$ \\
\hline Counts Subjects $(n=20,046)$ & & 182 & 2699 & 7286 & 7230 & 2650 \\
\hline Age - mean \pm SE & $45.28 \pm 0.3$ & $52.81 \pm 1.55$ & $54.78 \pm 0.61$ & $49.11 \pm 0.38$ & $41.5 \pm 0.34$ & $34.71 \pm 0.3$ \\
\hline Poverty Income Ratio - mean \pm SE & $2.99 \pm 0.04$ & $3.01 \pm 0.15$ & $3.13 \pm 0.05$ & $3.15 \pm 0.05$ & $2.92 \pm 0.04$ & $2.56 \pm 0.07$ \\
\hline Calories Consumed - mean \pm SE & $2189.13 \pm 10.36$ & $1490.34 \pm 70.36$ & $1821.13 \pm 19.67$ & $2134.69 \pm 14.34$ & $2342.11 \pm 17.73$ & $2356.4 \pm 30.02$ \\
\hline $\mathrm{BMI}-\operatorname{mean} \pm \mathrm{SE}$ & $28.13 \pm 0.1$ & $28.08 \pm 0.82$ & $27.47 \pm 0.15$ & $27.76 \pm 0.13$ & $28.37 \pm 0.1$ & $29.14 \pm 0.19$ \\
\hline female - count (\%) & & $112(0.62)$ & $1618(0.6)$ & $3851(0.53)$ & $3594(0.5)$ & $1310(0.49)$ \\
\hline white - count (\%) & & $107(0.59)$ & $1682(0.62)$ & $3790(0.52)$ & $2921(0.4)$ & $1097(0.41)$ \\
\hline black - count (\%) & & $20(0.11)$ & $294(0.11)$ & $1189(0.16)$ & $1860(0.26)$ & $855(0.32)$ \\
\hline mexican - count (\%) & & $37(0.2)$ & $529(0.2)$ & $1731(0.24)$ & $1873(0.26)$ & $487(0.18)$ \\
\hline other hispanic - count (\%) & & $9(0.05)$ & $100(0.04)$ & $295(0.04)$ & $320(0.04)$ & 105 (0.04) \\
\hline
\end{tabular}

\subsection{Correlation between $i F \operatorname{Pro}_{W G}, i F \operatorname{Pro}_{W C}$, and HEI-15}

While we find an overall agreement in the population ranking determined by $i F P r O_{W G}$ and $i F \operatorname{Pro}_{W C}\left(\rho_{\text {Spearman }}=0.7029\right.$, Figure $\left.\mathrm{S} 6 \mathrm{~A}\right)$, the two measures show significantly different patterns in epidemiological associations, in particular regarding chemical exposures (Figure 512 . Indeed, a weight-based index could capture complex dietary patterns arising from consumption of highly processed beverages such as zero-calorie soft drinks, or any type of food contaminants whose amount is independent from the provided calories.

We compared $i F$ Pro $_{W G}$ and $i F$ Pro $_{W C}$ with the Healthy Eating Index (HEI-2015), a score measuring the alignment of an individual's diet with the national dietary guidelines, ranging from 0 (no alignment) to 100 (complete alignment) [14]. We followed the National Cancer Institute (NCI) to calculate HEI-15 for NHANES participants 15. As expected, we observe negative correlations emerging (Figures $\mathrm{S} 6 \mathrm{~B}$ and $\mathrm{C})$, with both $i$ FPro ${ }_{W G}\left(\rho_{\text {Spearman }}=-0.4862\right)$, and 
medRxiv preprint doi: https://doi.org/10.1101/2021.05.22.21257615; this version posted May 25,2021 . The copyright holder for this preprint (which was not certified by peer review) is the author/funder, who has granted medRxiv a license to display the preprint in perpetuity.

$\left.i F \operatorname{ProWC}_{\text {Spearman }}=-0.5575\right)$.

A

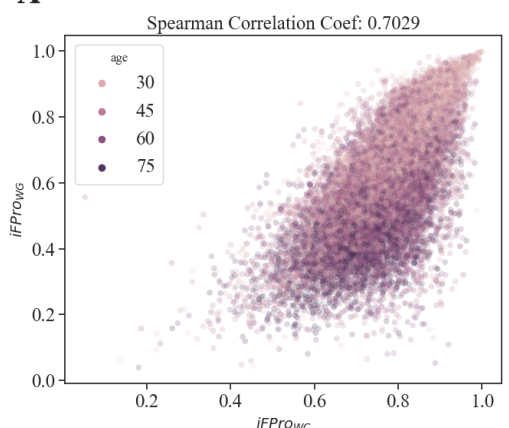

$\mathbf{B}$

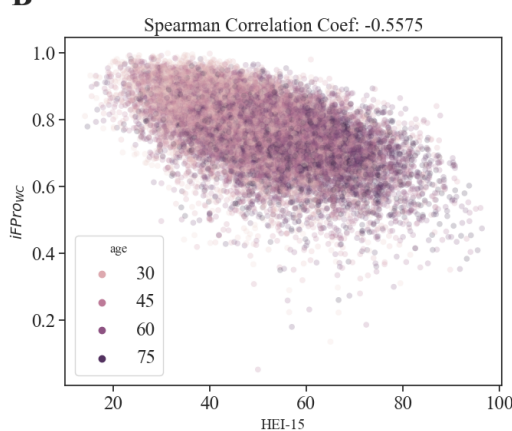

C

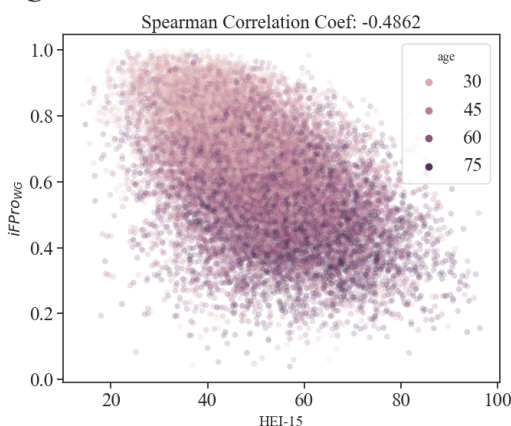

Figure SI. 6: Spearman's Correlation coefficients Between Two Variations of iFPro and Healthy Eating Index 2015.

Individual $\mathcal{A} \underset{\mathrm{O}}{\mathrm{O}} 47$ age

\begin{tabular}{|c|c|c|c|c|c|}
\hline & Food Cod & & Calories & FPro & Grams \\
\hline & 63107010 & Banana (raw) & 121 & 0.00 & 136 \\
\hline & 72201100 & Broccoli (raw) & 30 & 0.02 & 88 \\
\hline & 75115000 & Mushrooms (raw) & 30 & 0.17 & 138 \\
\hline & 74101000 & Tomatoes (raw) & 71 & 0.07 & 394 \\
\hline & 75114000 & Mixed greens salad & 31 & 0.09 & 182 \\
\hline & 24124120 & Fried Chicken breast & 232 & 0.56 & 120 \\
\hline & 22101220 & Fried Pork chop (lean) & 189 & 0.63 & 117 \\
\hline & 56205008 & Rice (cooked white) & 663 & 0.69 & 513 \\
\hline & 61210250 & Orange juice & 211 & 0.00 & 450 \\
\hline & 92410550 & Soft drink (caffeine add) & 68 & 1.00 & 185 \\
\hline & 92302000 & Tea (unsweetened) & 22 & 0.05 & 2131 \\
\hline
\end{tabular}

Individual $\mathcal{B} \underset{\mathrm{O}}{\mathrm{O}} 48$ age

\begin{tabular}{|c|c|c|c|c|}
\hline \multicolumn{2}{|c|}{ Food Code } & \multirow{2}{*}{$\begin{array}{l}\begin{array}{l}\text { Calories } \\
\text { (kcal) } \\
27\end{array} \\
\text { a }\end{array}$} & \multicolumn{2}{|c|}{ FPro Grams } \\
\hline 63109010 & Cantaloupe (raw) & & 0.02 & 78 \\
\hline 14010100 & Cheddar cheese & 32 & 0.51 & 9 \\
\hline 63223020 & Strawberries (raw) & 9 & 0.00 & 28 \\
\hline 92111010 & Coffee (decaffeinated) & 0 & 0.02 & 192 \\
\hline 92101000 & Coffee (regular) & 7 & 0.00 & 607 \\
\hline 57230000 & Cereal (Grape-Nuts) & 139 & 1.00 & 39 \\
\hline 53242000 & Cookie (sugar wafer) & 141 & 0.99 & 28 \\
\hline 54337000 & Cracker & 80 & 0.99 & 19 \\
\hline 25210110 & Hot dog (frankfurter) & 184 & 0.99 & 57 \\
\hline 27510560 & Hamburger (with mayonnaise) & 655 & 1.00 & 290 \\
\hline 51150000 & Bread roll (white, soft) & 145 & 1.00 & 52 \\
\hline 26137190 & Salmon (smoked) & 15 & 0.50 & 13 \\
\hline 71201020 & Potato chips & 59 & 0.91 & 12 \\
\hline 71401030 & French fries & 306 & 0.95 & 98 \\
\hline 75506010 & Mustard & 7 & 0.54 & 10 \\
\hline 91705030 & Kit Kat & 78 & 1.00 & 15 \\
\hline 11422000 & Yogurt (flavored and lowfat milk) & 156 & 0.99 & 184 \\
\hline 92410510 & Soft drink (caffeine free) & 49 & 0.99 & 122 \\
\hline
\end{tabular}

$63201010 \quad$ Blackberries (raw) $\quad 11 \quad 0.01 \quad 26$ 63219020 Raspberries (raw) $\quad 10 \quad 0.00 \quad 19$ $\begin{array}{lllll}92101000 & \text { Coffee (regular) } & 7 & 0.00 & 696\end{array}$ $57230000 \quad$ Cereal (Grape-Nuts) $\quad 312 \quad 1.00 \quad 87$ $53209000 \quad$ Cookie (chocolate) $\quad 206 \quad 1.00 \quad 44$ 53112100 Cake $\quad 382 \quad 1.00 \quad 141$ 58106225 Pizza (cheese) $\quad 622 \quad 1.00 \quad 234$ $11423000 \quad$ Yogurt (flavored and nonfat milk) $149 \quad 0.84 \quad 184$

Figure SI. 7: Dietary Recalls for Individual $\mathcal{A}$ (SEQN 68484) and Individual $\mathcal{B}$ (SEQN-ID 59440) annotated in Figure 2.

\subsection{Water Consumption in NHANES}

To calculate $i F P S_{W G}$ (Equation $\mathrm{S} 4$ ), we removed four food codes regarding water consumption, as their reporting through different NHANES cycles showed inconsistencies. Indeed, we 
medRxiv preprint doi: https://doi.org/10.1101/2021.05.22.21257615; this version posted May 25,2021 . The copyright holder for this preprint (which was not certified by peer review) is the author/funder, who has granted medRxiv a license to display the preprint in perpetuity.

It is made available under a CC-BY-NC-ND 4.0 International license.

noticed that "Water as an ingredient" stopped being tracked since NHANES 2011-2012 (Figure S8 A), and the consumption of tap and bottled water started being recorded since NHANES 2003-2004 (Figures $\mathrm{S} 8 \mathrm{~B}$ and C). These inconsistencies would have affected our analysis of the pooled cohorts.

A

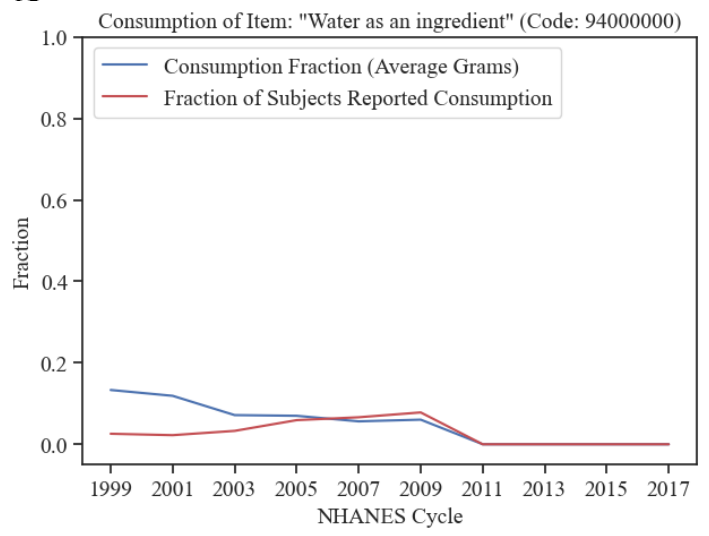

C

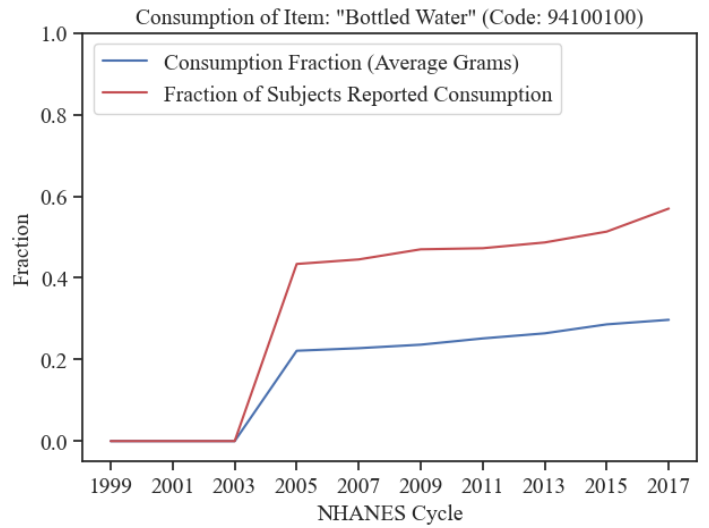

B

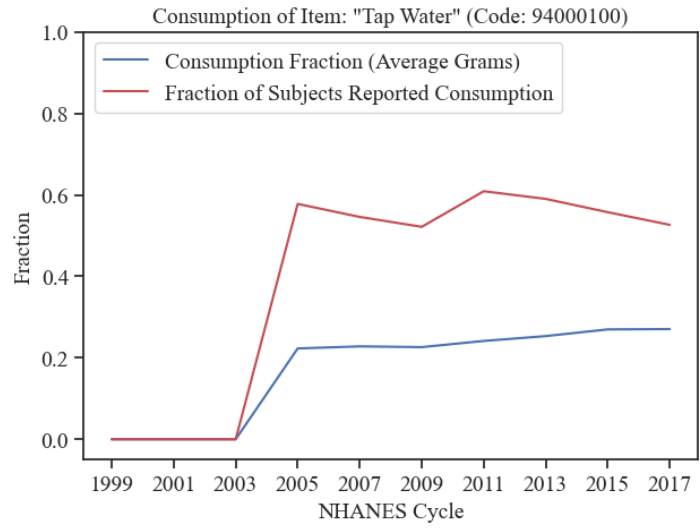

$\mathrm{D}$

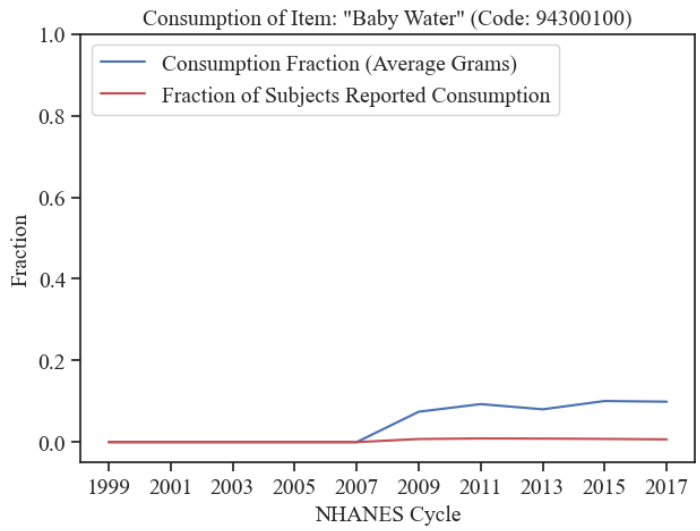

Figure SI. 8: Water Consumption in Survey Data. (a) "Water as an ingredient" is no longer tracked since NHANES 2011-2012. (b-c) Bottled and tap water have been tracked since NHANES 2005-2006, hence this might introduce inconsistency when combining NHANES 1999-2004 cohorts with their succeeding cohorts. (d) The consumption of baby water has been tracked since NHANES 2009-2010. 
medRxiv preprint doi: https://doi.org/10.1101/2021.05.22.21257615; this version posted May 25 , 2021 . The copyright holder for this preprint (which was not certified by peer review) is the author/funder, who has granted medRxiv a license to display the preprint in perpetuity.

\section{Environment-Wide Association Study}

Inspired by [16], we performed an Environment-Wide Association Study (EWAS) on the merged NHANES 1999-2006 cohort, to identify environmental factors and disease-related phenotypes associated with $i F$ Pro $_{W C}, i F \operatorname{Pro}_{W G}$, and fraction of calories contributed by manual NOVA 4. To do so, we collected data for 45 exposure modules in [11], and we further added one variable predicting diabetes according to fasting glucose levels $\geq 126 \mathrm{mg} / \mathrm{dL}$, as advised by the American Diabetes Association [17, two variables predicting metabolic syndrome [18, two assessments of the Framingham Risk Score [19, 20], and the ACC/AHA Risk Score [21], quantifying the 10-year risk of non-fatal myocardial infarction (MI), congestive heart disease (CHD) death, or fatal or nonfatal stroke.

The variables are broadly categorized in two panels (Figure S9A): a health panel, gathering variables describing the overall health of the individuals, from biological age and nutrient biomarkers, to disease phenotypes, and a chemical panel, where we group all chemical exposures measured in blood or urines, linked to pesticides, contaminants, and processing chemical byproducts.

To select the most robust signal, we studied only variables measured in at least two cycles of NHANES. To quantify the statistical associations, we employed the Survey-weighted Generalized Linear Model, and in particular, linear regression to predict continuous variables, and logistic regression for categorical (Figure $\mathrm{s} 9 \mathrm{~B}$ ). All models were adjusted for age, sex, ethnicity, Body Mass Index (BMI), total-caloric intake, and estimated Socioeconomic Status (SES), as provided by NHANES. We employed the 'survey' statistical package in R to account for the complex survey design of NHANES [13]. We further filtered all categorical and continuous variables lacking a minimum sample size to perform regression analysis. In particular, for continuous variables we considered a ratio between number of covariates and number of data points $\leq 1 / 50$, while for categorical we applied a similar threshold for the ratio between number of covariates and number of data points in the smallest category (Figure $\mathrm{S} 9 \mathrm{C}$ ).

All continuous variables were transformed using Box-Cox transformation or logit function (applied to Framingham and ACC/AHA scores) to stabilize the variance and improve the validity of measures of association [16. We then standardized all continuous variables, to bring their effect sizes on similar scale. For multiple linear regression, we used fully standardized regression coefficients, indicating how many standard deviations of change in the dependent 
medRxiv preprint doi: https://doi.org/10.1101/2021.05.22.21257615; this version posted May 25,2021 . The copyright holder for this preprint (which was not certified by peer review) is the author/funder, who has granted medRxiv a license to display the preprint in perpetuity.

It is made available under a CC-BY-NC-ND 4.0 International license.

variable are associated with one standard deviation increase in the independent variables. For logistic regression, we opted for a partial standardization, acting only on the continuous independent variables, as we wanted to keep a straightforward interpretation of the relation between one standard deviation increase in the Box-Cox transformed iF Pro and increase/decrease in disease odds 22 .

To account for false discovery rate, we adjusted the p-values corresponding to each score using Benjamini-Hochberg method with $\alpha=0.05$. Overall, we find 214 significant tests across the three methodologies, with $i F$ Pro $_{W C}$ at $134, i F$ Pro $_{W G}$ at 170, and manual NOVA 4 at 92. The summary of the analysis is presented in Figures s10, 513 , A comparison with literature results based on manual NOVA 4 is reported in Table $\$ 9$.

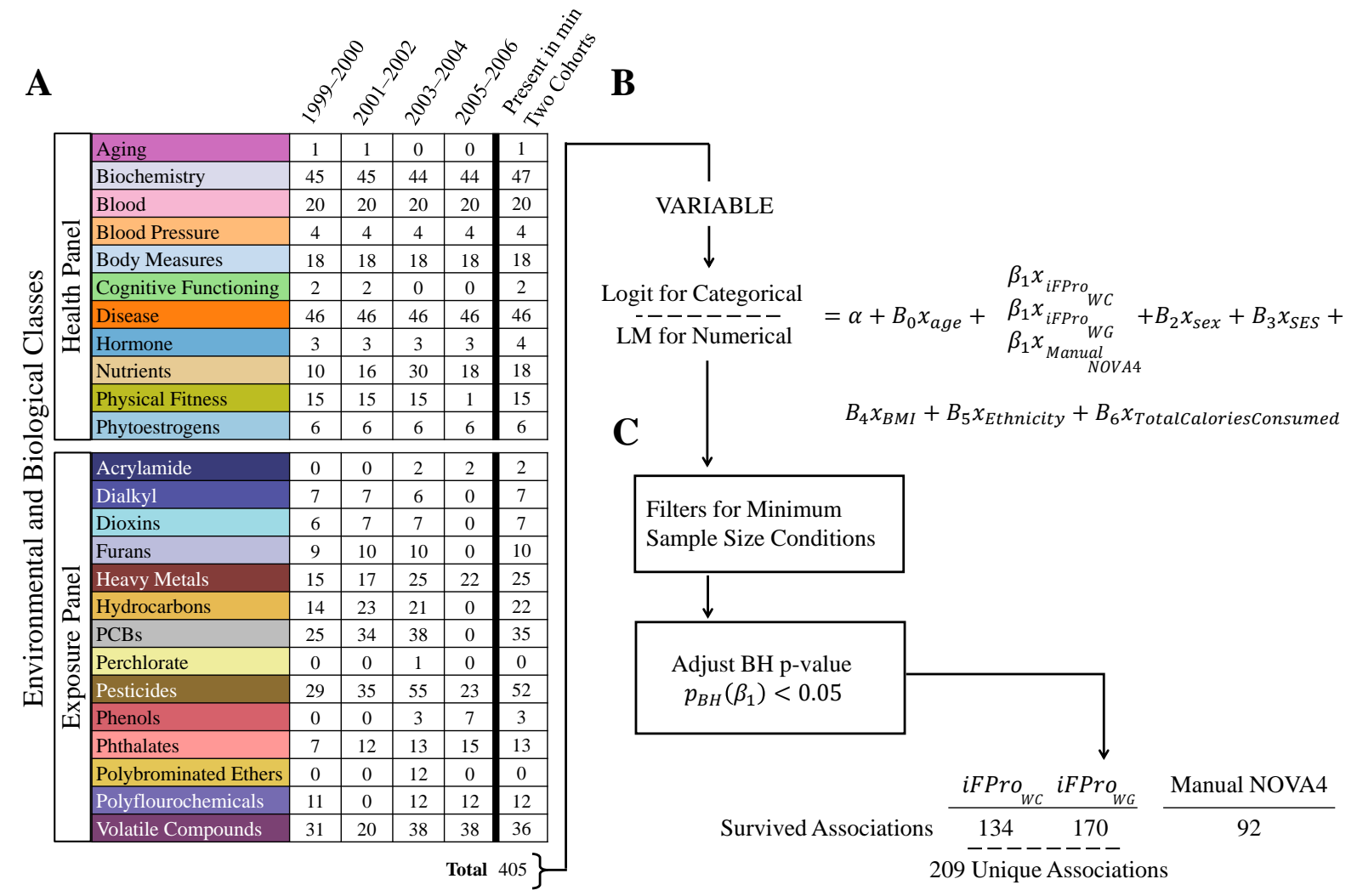

Figure SI. 9: Overview of the EWAS pipeline on NHANES 1999-2006. (a) For the selected health phenotypes and chemical exposures provided in each cohort of NHANES, we kept only those variables present in at least two cohorts. (b) We investigated possible associations between the selected 405 variables in the combined NHANES 1999-2006 cohort using linear regression for continuous variables and logistic regression for categorical variables. (c) To account for false discovery rate, we adjusted the p-value of $\beta_{1}$ using Benjamini-Hochberg method with $\alpha=0.05$. 
medRxiv preprint doi: https://doi.org/10.1101/2021.05.22.21257615; this version posted May 25, 2021. The copyright holder for this preprint (which was not certified by peer review) is the author/funder, who has granted medRxiv a license to display the preprint in perpetuity.

It is made available under a CC-BY-NC-ND 4.0 International license .

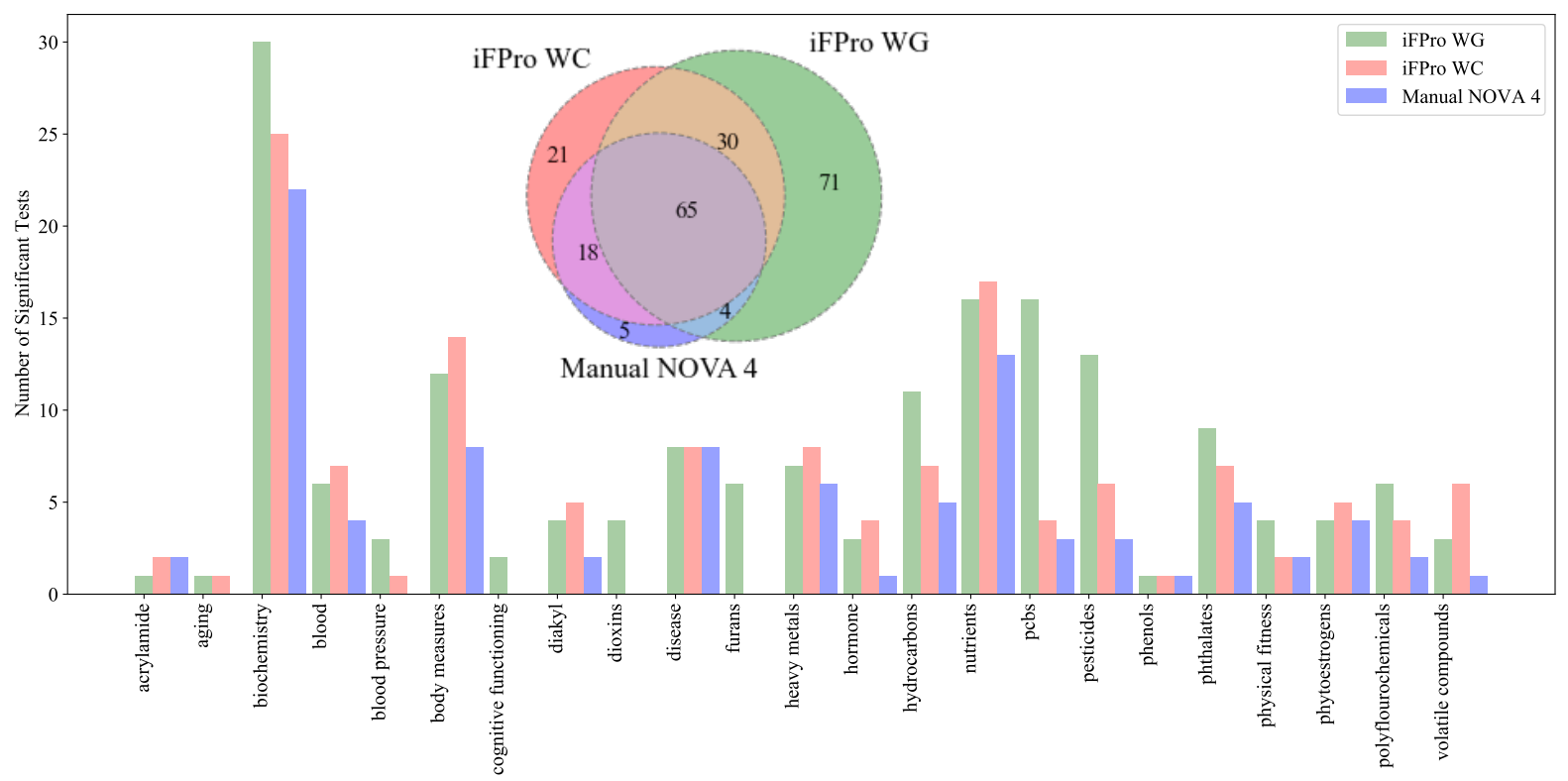

Figure SI. 10: Number of significant tests surviving multiple testing for $i F \operatorname{Pro}_{W C}, i F P r o_{W G}$, and fraction of caloric intake from manual NOVA 4. For $i F \operatorname{Pro}_{W G}$ and $i F \operatorname{Pro}_{W C}$, we find 170 and 134 significant associations, respectively, for a total of 209 unique variables. In comparison, the same analysis using the fraction of calories contributed by manual NOVA 4 finds 92 significant associations, of which $95 \%$ is in overlap with $i F$ Pro $_{W G}$ and $i F$ Pro $o_{W C}$. Overall, the total number of variables recovered by the three methodologies is 214 . Here we report the results stratified by module.
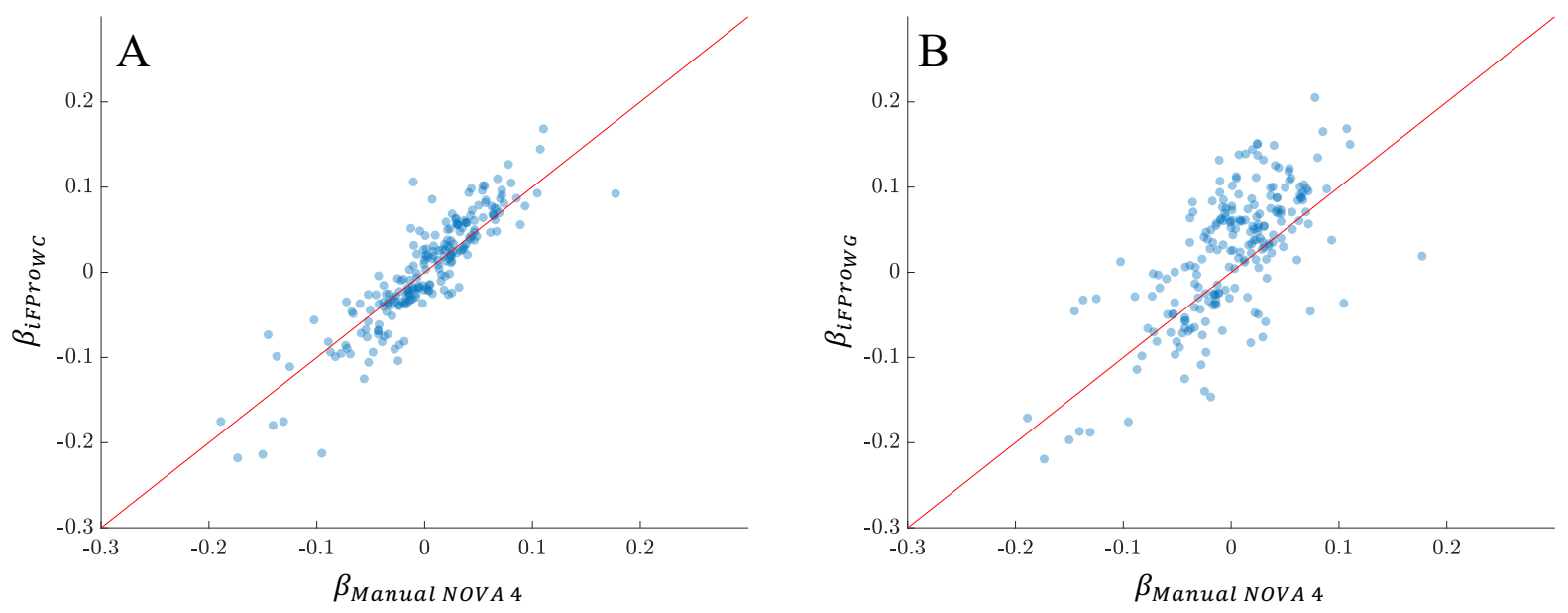

Figure SI. 11: Comparison of the Effect Sizes for the Significant Tests found by iFPro $_{W C}$, $i F P r o_{W G}$, and fraction of caloric intake from manual NOVA 4. Across the 214 significant variables recovered by the three methodologies we find that (a) $70.56 \%$ of the times $i F$ ProWC $_{W C}$ shows bigger effect sizes compared to manual NOVA 4 , while (b) for $i F$ Pro $_{W G}$ the percentage increases to $77.57 \%$. 
medRxiv preprint doi: https://doi.org/10.1101/2021.05.22.21257615; this version posted May 25, 2021. The copyright holder for this preprint (which was not certified by peer review) is the author/funder, who has granted medRxiv a license to display the preprint in perpetuity.

It is made available under a CC-BY-NC-ND 4.0 International license .



\author{
Acrylamide \\ Dialkyl \\ Dioxins
}
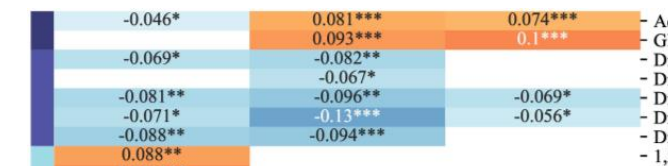

Acrylamide (pmoL/G Hb)

Dimethylphosphate (ug/L) Diethylphosphate (ug/L) - Dimethylthiophosphate (ug/L)

Diethylthiophosphate (ug/L)
Dimethyldithiophosphate (ug/L)

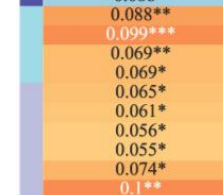

1,2,3,4,7,8-hxcdd (fg/g)

1,2,3,4,6,7,8,9-ocdd (fg/g)

$-2,3,7,8$-tcdd ( $(\mathrm{gg} / \mathrm{g})$

$2,3,7,8-\operatorname{tcdf}(\mathrm{fg} / \mathrm{g})$

Furans

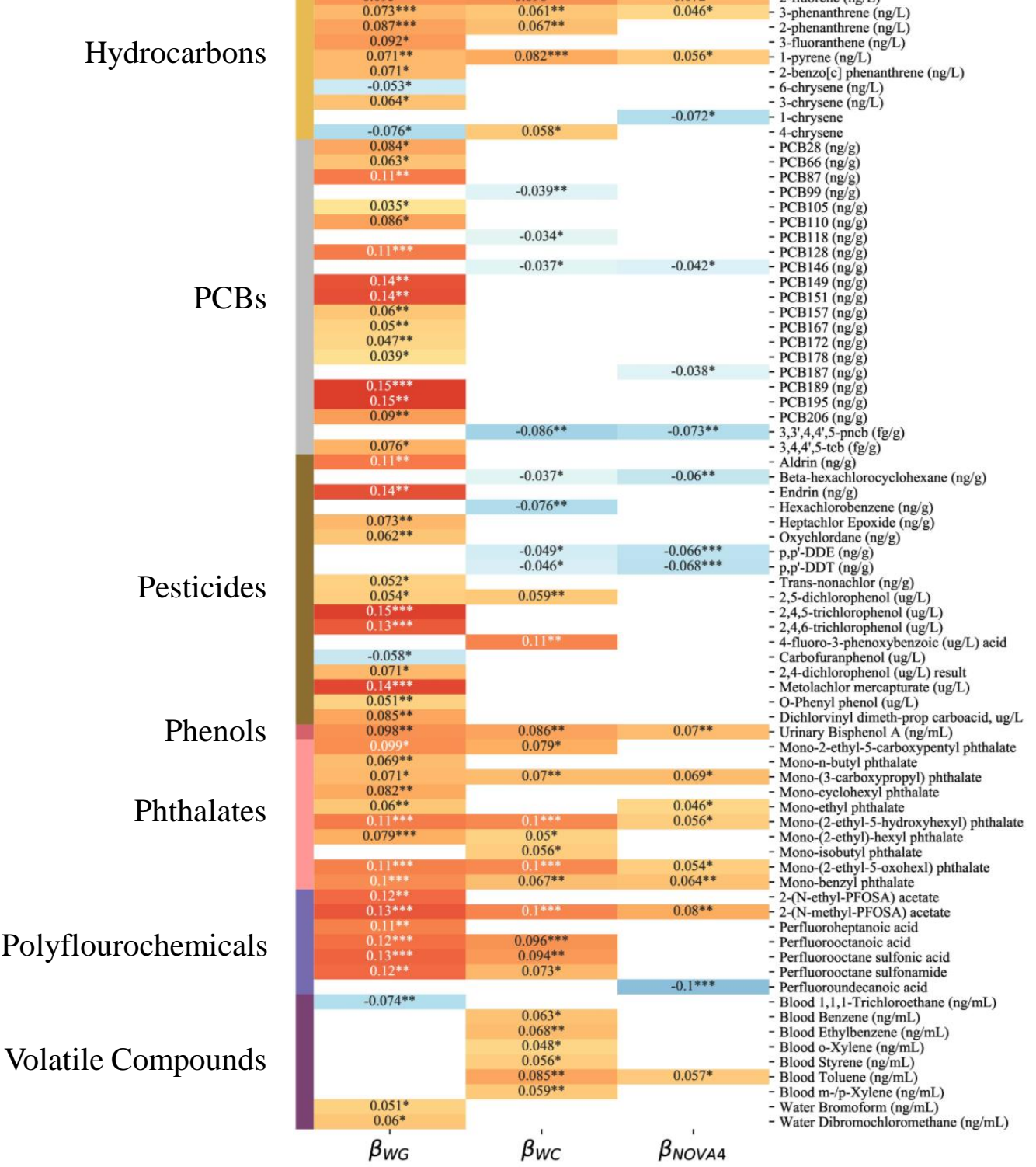

Figure SI. 12: Exposure Panel. Each variable reported on the left (e.g. "Acrylamide") refers to different exposure modules. We report here the standardized $\beta$ coefficient, quantifying the effect on each exposure when the Box-Cox transformed diet scores increase of one standard deviation over the population. Each variable is color-coded according to $\beta$, with positive associations in red, and negative associations in blue. In white, we annotate the variables that do not survive Benjamini-Hochberg FDR. 
medRxiv preprint doi: https://doi.org/10.1101/2021.05.22.21257615; this version posted May 25, 2021. The copyright holder for this preprint (which was not certified by peer review) is the author/funder, who has granted medRxiv a license to display the preprint in perpetuity. It is made available under a CC-BY-NC-ND 4.0 International license.

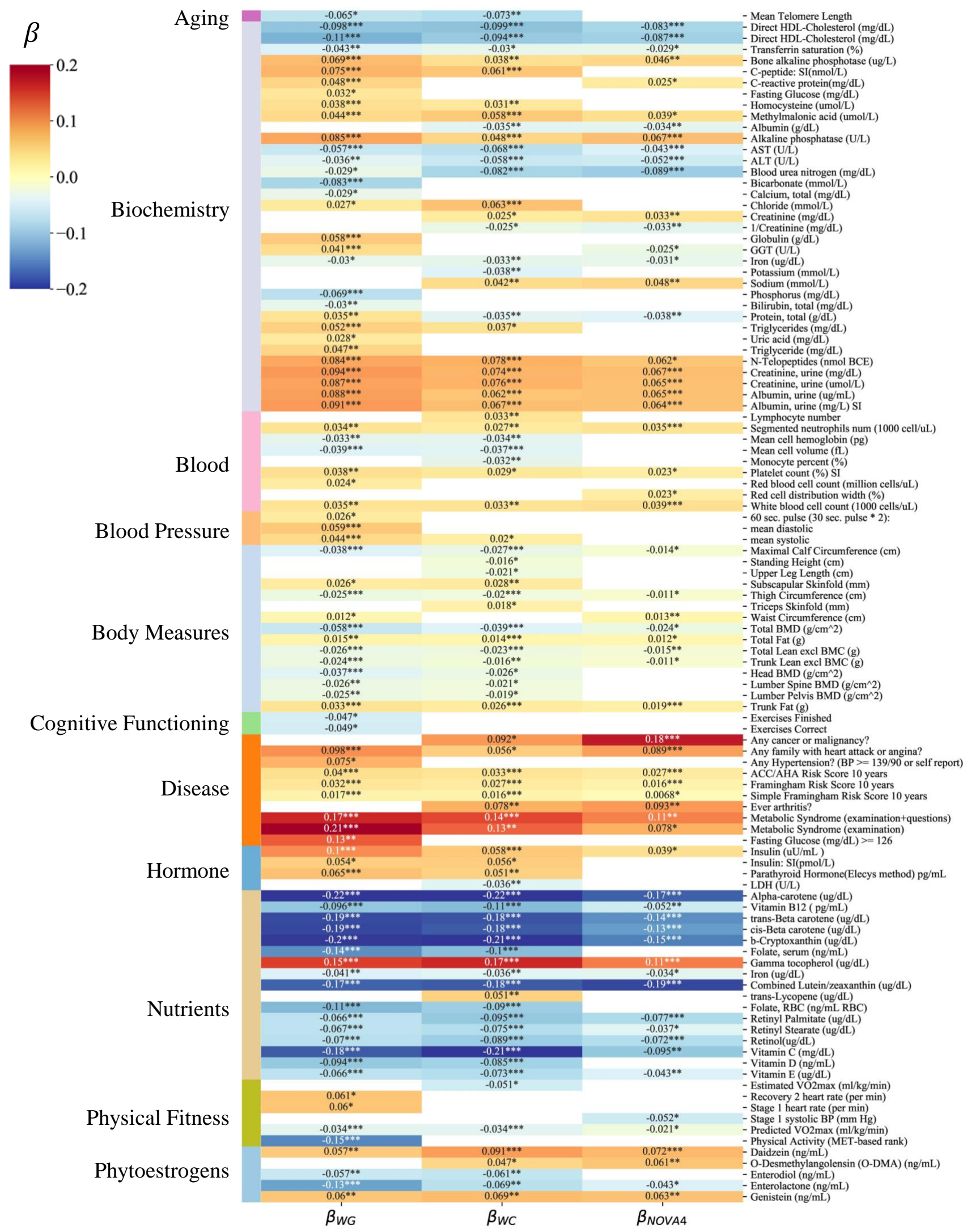

Figure SI. 13: Health Panel. Each variable reported on the left (e.g. "Aging") refers to different modules of disease phenotypes and measurements assessing the overall health status of each individual. We report here the standardized $\beta$ coefficient, quantifying the effect on each exposure when the Box-Cox transformed diet scores increase of one standard deviation over the population. Each variable is color-coded according to $\beta$, with positive associations in red, and negative associations in blue. In white, we annotate the variables that do not survive Benjamini-Hochberg FDR. 
medRxiv preprint doi: https://doi.org/10.1101/2021.05.22.21257615; this version posted May 25, 2021. The copyright holder for this preprint (which was not certified by peer review) is the author/funder, who has granted medRxiv a license to display the preprint in perpetuity.

It is made available under a CC-BY-NC-ND 4.0 International license .

Table 9: A Summary of the Epidemiological Literature on the Discovered Associations with Manual NOVA 4.

\begin{tabular}{|c|c|c|}
\hline $\begin{array}{l}\text { Health or } \\
\text { Exposure Panel }\end{array}$ & Paper & $\begin{array}{l}\text { In Agreement } \\
\text { with } i F \text { Pro }\end{array}$ \\
\hline Aging & $\begin{array}{l}\text { Ultra-processed food consumption and the risk of short } \\
\text { telomeres in an elderly population of the Seguimiento } \\
\text { Universidad de Navarra (SUN) Project } 23 \text { Spain (SUN) }\end{array}$ & Yes \\
\hline $\begin{array}{l}\text { Disease: } \\
\text { Cardiovascular }\end{array}$ & $\begin{array}{l}\text { - Association between ultraprocessed food intake and } \\
\text { cardiovascular health in US adults: a cross-sectional } \\
\text { analysis of the NHANES 2011-2016 } \\
\text { USA (NHANES) } \\
\text { - Ultra-processed food intake and risk of cardiovascular } \\
\text { disease: prospective cohort study (NutriNet-Santé) 25] } \\
\text { France (NutriNet-Santé) } \\
\text { Ultra-processed food consumption is associated with } \\
\text { increased risk of all-cause and cardiovascular mortality } \\
\text { in the Moli-sani Study } 26 \text { Molise, Italy (Moli-sani) }\end{array}$ & Yes \\
\hline $\begin{array}{l}\text { Disease: } \\
\text { Hypertension }\end{array}$ & $\begin{array}{l}\text { Ultra-processed food consumption and the incidence of } \\
\text { hypertension in a mediterranean cohort: The seguimiento } \\
\text { universidad de navarra project } 27] \text { Spain (SUN) }\end{array}$ & Yes \\
\hline
\end{tabular}


medRxiv preprint doi: https://doi.org/10.1101/2021.05.22.21257615; this version posted May 25, 2021. The copyright holder for this preprint (which was not certified by peer review) is the author/funder, who has granted medRxiv a license to display the preprint in perpetuity.

It is made available under a CC-BY-NC-ND 4.0 International license .

Table 9 - continued from previous page

\begin{tabular}{|c|c|c|}
\hline $\begin{array}{l}\text { Health or } \\
\text { Exposure Panel }\end{array}$ & Paper & $\begin{array}{l}\text { In Agreement } \\
\text { with } i F \text { Pro }\end{array}$ \\
\hline $\begin{array}{l}\text { Disease: } \\
\text { Metabolic } \\
\text { Syndrome }\end{array}$ & $\begin{array}{l}\text { - Dietary share of ultra-processed foods and metabolic } \\
\text { syndrome in the US adult population } 28] \\
\text { - } \text { USA (NHANES) } \\
\text { in an Indigenous Cree (Eeyouch) population in northern } \\
\text { Québec, Canada } 29] \\
\text { Canada (Aschii Environment \& Health Study) } \\
\text { - A minimally processed dietary pattern is associated } \\
\text { with lower odds of metabolic syndrome among Lebanese } \\
\text { adults } 30 \text { Lebanon }\end{array}$ & Yes \\
\hline $\begin{array}{l}\text { Disease: } \\
\text { Cancer }\end{array}$ & $\begin{array}{l}\text { Consumption of ultra-processed foods and cancer risk: } \\
\text { results from NutriNet-Santé prospective cohort } 31 \\
\text { France (NutriNet-Santé) }\end{array}$ & Yes \\
\hline $\begin{array}{l}\text { Body Measures: } \\
\text { Total Fat }\end{array}$ & $\begin{array}{l}\text { Contribution of ultra-processed foods in visceral fat } \\
\text { deposition and other adiposity indicators: Prospective } \\
\text { analysis nested in the PREDIMED-Plus trial } 32 \\
\text { Spain (PREDIMED-Plus) }\end{array}$ & Yes \\
\hline
\end{tabular}


medRxiv preprint doi: https://doi.org/10.1101/2021.05.22.21257615; this version posted May 25, 2021. The copyright holder for this preprint (which was not certified by peer review) is the author/funder, who has granted medRxiv a license to display the preprint in perpetuity.

It is made available under a CC-BY-NC-ND 4.0 International license.

Table 9 - continued from previous page

\begin{tabular}{|c|c|c|}
\hline $\begin{array}{l}\text { Health or } \\
\text { Exposure Panel }\end{array}$ & Paper & $\begin{array}{l}\text { In Agreement } \\
\text { with } i F \text { Pro }\end{array}$ \\
\hline $\begin{array}{l}\text { Body Measures: } \\
\text { Waist } \\
\text { Circumference }\end{array}$ & $\begin{array}{l}\text { - Ultra-processed food consumption and excess weight } \\
\text { among US adults } 33 \text { USA (NHANES) } \\
\text { - Consumption of ultra-processed food and obesity: cross } \\
\text { sectional results from the Brazilian Longitudinal Study } \\
\text { of Adult Health (ELSA-Brasil) cohort (2008-2010) } 34 \\
\text { Brazil (ELSA) } \\
\text { - Ultra-processed food consumption and indicators of } \\
\text { obesity in the United Kingdom population } \\
\text { (2008-2016) } 35 \text { UK (NDNS) }\end{array}$ & Yes \\
\hline Nutrients & $\begin{array}{l}\text { - The share of ultra-processed foods and the overall } \\
\text { nutritional quality of diets in the US: evidence from a } \\
\text { nationally representative cross-sectional study } 36 \\
\text { USA (NHANES) } \\
\text { - Impact of ultra-processed foods on micronutrient } \\
\text { content in the Brazilian diet } 37 \text { Brazil (HBS) }\end{array}$ & Yes \\
\hline $\begin{array}{l}\text { Biochemistry: } \\
\text { C-Reactive } \\
\text { Protein }\end{array}$ & $\begin{array}{l}\text { Association between consumption of ultra-processed foods } \\
\text { and serum C-reactive protein levels: cross-sectional results } \\
\text { from the ELSA-Brasil study } 38 \text { Brazil (ELSA) }\end{array}$ & Yes \\
\hline Phytoestrogens & $\begin{array}{l}\text { Association between dietary share of ultra-processed foods } \\
\text { and urinary concentrations of phytoestrogens in the } \\
\text { US } 39 \text { USA (NHANES) }\end{array}$ & Yes \\
\hline $\begin{array}{l}\text { Vegetarian Diet: } \\
\text { Adverse Effects of } \\
\text { ultra-processing }\end{array}$ & $\begin{array}{l}\text { Consumption of Ultra-Processed Foods by } \\
\text { Pesco-Vegetarians, Vegetarians, and Vegans: Associations } \\
\text { with Duration and Age at Diet Initiation } 40 \\
\text { France (NutriNet-Santé) }\end{array}$ & Yes \\
\hline
\end{tabular}


medRxiv preprint doi: https://doi.org/10.1101/2021.05.22.21257615; this version posted May 25, 2021. The copyright holder for this preprint (which was not certified by peer review) is the author/funder, who has granted medRxiv a license to display the preprint in perpetuity.

It is made available under a CC-BY-NC-ND 4.0 International license .

Table 9 - continued from previous page

\begin{tabular}{|c|c|c|}
\hline $\begin{array}{l}\text { Health or } \\
\text { Exposure Panel }\end{array}$ & Paper & $\begin{array}{l}\text { In Agreement } \\
\text { with } i F \text { Pro }\end{array}$ \\
\hline $\begin{array}{l}\text { Phthalates and } \\
\text { Phenols }\end{array}$ & $\begin{array}{l}\text { - Ultra-processed food consumption and exposure to } \\
\text { phthalates and bisphenols in the US National Health } \\
\text { and Nutrition Examination Survey, 2013-2014 } 41 \\
\text { USA (NHANES) } \\
\text { - Association between dietary contribution of } \\
\text { ultra-processed foods and urinary concentrations of } \\
\text { phthalates and bisphenol in a nationally representative } \\
\text { sample of the US population aged } 6 \text { years and older } 42 \\
\text { USA (NHANES) }\end{array}$ & Yes \\
\hline Acrylamides & $\begin{array}{l}\text { Association between Heat-Induced Chemical Markers and } \\
\text { Ultra-Processed Foods: A Case Study on Breakfast } \\
\text { Cereals } 43 \text { Spanish supermarkets }\end{array}$ & Yes \\
\hline
\end{tabular}

\section{Food Substitution}

The observed variability of F Pro for categories of foods similarly consumed in the population (Figure 2E), combined with the EWAS results, quantifying the effect of processed diet on disease risk, suggests a systematic way to implement food substitution and predict its relevance in terms of health indicators 44, 45]. With this goal, we classified all foods consumed by the pooled cohort of 20,047 individuals in NHANES 1999-2006, according to WWEIA [46]. For substitution purposes, the relevance of food $k$ in individual $j$ 's diet can be quantified as

$$
r_{k}^{j}=f_{C}^{(k, j)}\left(\text { Pro }_{k}-\text { FPro }_{\min W W E I A(k)}\right)
$$

where $f_{C}^{(k, j)}$ is the fraction of calories contributed by food $k$ to the dietary profile, while FPromin WWEIA(k) refers to the food with the lowest F Pro within the same WWEIA category of food $k$. By picking the suggested foods in the original WWEIA classes reported by each individual, we aim to minimally perturb her habits, to maximize the compliance to the new dietary regime. Moreover, as Eq. \$5 offers a heuristic to identify which food to prioritize, the overall level of processing is reduced in a minimal number of steps. 
medRxiv preprint doi: https://doi.org/10.1101/2021.05.22.21257615; this version posted May 25, 2021. The copyright holder for this preprint (which was not certified by peer review) is the author/funder, who has granted medRxiv a license to display the preprint in perpetuity.

It is made available under a CC-BY-NC-ND 4.0 International license .

The impact of substituting $M$ foods on disease risk is measured in terms of odds ratio (OR), that quantifies the odds of disease occurring when adopting the optimized diet, compared to the original choices. We estimate OR as

$$
O R_{(\text {Sub vs Orig })}^{j}=e^{\beta_{1}\left[\left(i F P r o_{W C}^{j}-\sum_{m=1}^{M} r_{m}^{j}\right)^{t}-\left(i F P r o_{W C}^{j}\right)^{t}\right]}
$$

where $\beta_{1}$ is the effect size describing the strength of the association between iFPro and disease onset, all $\left\{r_{m}^{j}\right\}$ follow from Eq. $\$ 5$, and with the superscript $t$ we denote the functioncomposition of Box-Cox transformation followed by z-score with parameters estimated in the original population.

For continuous variables $y$ like vitamin $B_{12}$, vitamin $\mathrm{C}$, and bisphenol $\mathrm{A}$, the impact of substituting $M$ foods on individual $j$ 's diet is quantified by

$$
\frac{y_{\text {Sub }}^{j}}{y_{\text {Orig }}^{j}}=\frac{\left\{\left(y_{\text {Orig }}^{j}\right)^{t}+\beta_{1}\left[\left(i F \operatorname{Pro}_{W C}^{j}-\sum_{m=1}^{M} r_{m}^{j}\right)^{t}-\left(i F \operatorname{Pro}_{W C}^{j}\right)^{t}\right]\right\}^{-t}}{y_{\text {Orig }}^{j}},
$$

where with the superscript $-t$ we refer to the inverse function-composition of Box-Cox transformation followed by standardization (first invert z-score, then Box-Cox). 
medRxiv preprint doi: https://doi.org/10.1101/2021.05.22.21257615; this version posted May 25, 2021. The copyright holder for this preprint (which was not certified by peer review) is the author/funder, who has granted medRxiv a license to display the preprint in perpetuity.

It is made available under a CC-BY-NC-ND 4.0 International license .

\section{References}

[1] FDA Nutrition Facts. https://www.fda.gov/media/99331/download.

[2] USDA FoodData Central. https://fdc.nal.usda.gov/.

[3] Ahuja, J. et al. USDA Food and Nutrient Database for Dietary Studies, 5.0. U.S. Department of Agriculture, Agricultural Research Service, Food Surveys Research Group, Beltsville, MD. http://www.ars.usda.gov/ba/bhnrc/fsrg (2012).

[4] Sebastian, R. S. et al. Flavonoid Values for USDA Survey Foods and Beverages 2007-2010. U.S. Department of Agriculture, Agricultural Research Service, Food Surveys Research Group, Beltsville, MD. http://www.ars.usda.gov/nea/bhnrc/fsrg (2016).

[5] USDA National Nutrient Database for Standard Reference (SR). URL https://data.nal.usda.gov/dataset/ usda-national-nutrient-database-standard-reference-legacy-release.

[6] USDA FoodData Central (FDC). URL https://fdc.nal.usda.gov/.

[7] Steele, E. M. et al. Ultra-processed foods and added sugars in the US diet: Evidence from a nationally representative cross-sectional study. BMJ Open 6, 1-8 (2016).

[8] Database of Flavonoid Values for USDA Food Codes 2007-2010 and Flavonoid Intake Data Files from What We Eat in America (WWEIA), National Health and Nutrition Examination Survey (NHANES) 2007-2010 . URL https://www.ars.usda.gov/northeast-area/ beltsville-md-bhnrc/beltsville-human-nutrition-research-center/ food-surveys-research-group/docs/fndds-flavonoid-database/.

[9] Menichetti, G. \& Barabasi, A.-L. Universal Scaling of Nutrient Concentrations in Food. Submitted for publication (Nature Food) 1-66 (2021).

[10] Chawla, N. V., Bowyer, K. W., Hall, L. O. \& Kegelmeyer, W. P. SMOTE: Synthetic minority over-sampling technique. Journal of Artificial Intelligence Research 16, 321-357 (2002). 1106.1813

[11] Patel, C. J. et al. A database of human exposomes and phenomes from the us national health and nutrition examination survey. Scientific Data 3, 160096 (2016). URL https: //doi.org/10.1038/sdata.2016.96.

[12] NHANES Survey Methods and Analytic Guidelines. URL https://wwwn.cdc.gov/nchs/ nhanes/analyticguidelines.aspx 
medRxiv preprint doi: https://doi.org/10.1101/2021.05.22.21257615; this version posted May 25, 2021. The copyright holder for this preprint (which was not certified by peer review) is the author/funder, who has granted medRxiv a license to display the preprint in perpetuity.

It is made available under a CC-BY-NC-ND 4.0 International license .

[13] Lumley, T. survey: analysis of complex survey samples (2020). R package version 4.0.

[14] Healthy Eating Index (HEI) . URL https://www.fns.usda.gov/resource/ healthy-eating-index-hei

[15] National cancer institute. developing the healthy eating index. bethesda, md: National cancer institute. https://epi.grants.cancer.gov/hei/developing.html. 2020 (accessed September 1, 2020).

[16] Milanlouei, S. et al. A systematic comprehensive longitudinal evaluation of dietary factors associated with acute myocardial infarction and fatal coronary heart disease. Nature Communications 11, 1-14 (2020). URL https://doi.org/10.1038/s41467-020-19888-2.

[17] Patel, C. J., Bhattacharya, J. \& Butte, A. J. An environment-wide association study (EWAS) on type 2 diabetes mellitus. PLOS ONE 5 (2010).

[18] Moore, J., Chaudhary, N. \& Akinyemiju, T. Metabolic syndrome prevalence by race/ethnicity and sex in the united states, national health and nutrition examination survey, 1988-2012. Prev Chronic Dis (2017).

[19] D'Agostino, R. B. et al. General cardiovascular risk profile for use in primary care: The Framingham heart study. Circulation 117, 743-753 (2008).

[20] Castro, V. CVrisk: Compute Risk Scores for Cardiovascular Diseases (2021). URL https: //github.com/vcastro/CVrisk. R package version 1.1.0.9000.

[21] Goff, D. C. et al. 2013 ACC/AHA guideline on the assessment of cardiovascular risk: A report of the American college of cardiology/American heart association task force on practice guidelines. Circulation 129, 49-73 (2014).

[22] Menard, S. Standards for standardized logistic regression coefficients. Social Forces 89, 1409-1428 (2011).

[23] Alonso-Pedrero, L. et al. Ultra-processed food consumption and the risk of short telomeres in an elderly population of the Seguimiento Universidad de Navarra (SUN) Project. The American journal of clinical nutrition 111, 1259-1266 (2020). URL https://academic. oup.com/ajcn/article/111/6/1259/5824715.

[24] Zhang, Z., Jackson, S. L., Martinez, E., Gillespie, C. \& Yang, Q. Association between ultraprocessed food intake and cardiovascular health in us adults: a cross-sectional analysis of the nhanes 2011-2016. The American Journal of Clinical Nutrition 113, 428-436 
medRxiv preprint doi: https://doi.org/10.1101/2021.05.22.21257615; this version posted May 25, 2021. The copyright holder for this preprint (which was not certified by peer review) is the author/funder, who has granted medRxiv a license to display the preprint in perpetuity.

It is made available under a CC-BY-NC-ND 4.0 International license.

(2020). URL https://doi.org/10.1093/ajcn/nqaa276.

https://academic.oup.com/ ajcn/article-pdf/113/2/428/36170430/nqaa276.pdf.

[25] Srour, B. et al. Ultra-processed food intake and risk of cardiovascular disease: prospective cohort study (nutrinet-santé). BMJ 365 (2019). URL https://www.bmj.com/content/ 365/bmj .11451. https://www.bmj.com/content/365/bmj.11451.full.pdf.

[26] Bonaccio, M. et al. Ultra-processed food consumption is associated with increased risk of all-cause and cardiovascular mortality in the Moli-sani Study. The American Journal of Clinical Nutrition 113, 446-455 (2020). URL https://doi.org/10.1093/ajcn/nqaa299. https://academic.oup.com/ajcn/article-pdf/113/2/446/36170506/nqaa299.pdf.

[27] De Deus Mendonça, R. et al. Ultra-processed food consumption and the incidence of hypertension in a mediterranean cohort: The seguimiento universidad de navarra project. American Journal of Hypertension 30, 358-366 (2017). URL https://pubmed.ncbi.nlm. nih.gov/27927627/.

[28] Martínez Steele, E., Juul, F., Neri, D., Rauber, F. \& Monteiro, C. A. Dietary share of ultra-processed foods and metabolic syndrome in the us adult population. Preventive Medicine 125, 40-48 (2019). URL https://www.sciencedirect.com/science/article/ pii/S0091743519301720.

[29] Lavigne-Robichaud, M. et al. Diet quality indices in relation to metabolic syndrome in an indigenous cree (eeyouch) population in northern québec, canada. Public Health Nutrition 21, 172-180 (2018).

[30] Nasreddine, L. et al. A minimally processed dietary pattern is associated with lower odds of metabolic syndrome among lebanese adults. Public Health Nutrition 21, 160-171 (2018).

[31] Fiolet, T. et al. Consumption of ultra-processed foods and cancer risk: results from nutrinet-santé prospective cohort. BMJ 360 (2018). URL https://www.bmj.com/ content/360/bmj.k322. https://www.bmj.com/content/360/bmj.k322.full.pdf.

[32] Konieczna, J. et al. Contribution of ultra-processed foods in visceral fat deposition and other adiposity indicators: Prospective analysis nested in the predimed-plus trial. Clinical Nutrition (2021). URL https://www.sciencedirect.com/science/article/pii/ S0261561421000297. 
medRxiv preprint doi: https://doi.org/10.1101/2021.05.22.21257615; this version posted May 25, 2021. The copyright holder for this preprint (which was not certified by peer review) is the author/funder, who has granted medRxiv a license to display the preprint in perpetuity.

It is made available under a CC-BY-NC-ND 4.0 International license.

[33] Juul, F., Martinez-Steele, E., Parekh, N., Monteiro, C. A. \& Chang, V. W. Ultra-processed food consumption and excess weight among us adults. British Journal of Nutrition 120, 90-100 (2018).

[34] Silva, F. M. et al. Consumption of ultra-processed food and obesity: cross sectional results from the brazilian longitudinal study of adult health (elsa-brasil) cohort (2008-2010). Public Health Nutrition 21, 2271-2279 (2018).

[35] Rauber, F. et al. Ultra-processed food consumption and indicators of obesity in the united kingdom population (2008-2016). PLOS ONE 15, 1-15 (2020). URL https://doi.org/ 10.1371/journal.pone.0232676.

[36] Martínez Steele, E., Popkin, B. M., Swinburn, B. \& Monteiro, C. A. The share of ultraprocessed foods and the overall nutritional quality of diets in the us: evidence from a nationally representative cross-sectional study. Population Health Metrics 15, 6 (2017). URL https://doi.org/10.1186/s12963-017-0119-3.

[37] Louzada, M. L. d. C. et al. Impact of ultra-processed foods on micronutrient content in the Brazilian diet. Revista de saude publica 49 (2015). URL https://doi.org/10.1590/ S0034-8910.2015049006211.

[38] Lopes, A. E. d. S. C., AraÃ, L. F., Levy, R. B., Barreto, S. M. \& Giatti, L. Association between consumption of ultra-processed foods and serum C-reactive protein levels: cross-sectional results from the ELSA-Brasil study. Sao Paulo Medical Journal 137, 169 - 176 (2019). URL http://www.scielo.br/scielo.php?script=sci_arttext\&pid= S1516-31802019000200169\&nrm=iso.

[39] Steele, E. M. \& Monteiro, C. A. Association between dietary share of ultra-processed foods and urinary concentrations of phytoestrogens in the US. Nutrients 9 (2017).

[40] Gehring, J. et al. Consumption of Ultra-Processed Foods by Pesco-Vegetarians, Vegetarians, and Vegans: Associations with Duration and Age at Diet Initiation. The Journal of Nutrition 151, 120-131 (2020). URL https://doi.org/10.1093/jn/nxaa196. https://academic.oup.com/jn/article-pdf/151/1/120/35365121/nxaa196.pdf.

[41] Buckley, J. P., Kim, H., Wong, E. \& Rebholz, C. M. Ultra-processed food consumption and exposure to phthalates and bisphenols in the US National Health and Nutrition Examination Survey, 2013-2014. Environment International 131 (2019). 
medRxiv preprint doi: https://doi.org/10.1101/2021.05.22.21257615; this version posted May 25, 2021. The copyright holder for this preprint (which was not certified by peer review) is the author/funder, who has granted medRxiv a license to display the preprint in perpetuity.

It is made available under a CC-BY-NC-ND 4.0 International license .

[42] Martínez Steele, E., Khandpur, N., da Costa Louzada, M. L. \& Monteiro, C. A. Association between dietary contribution of ultra-processed foods and urinary concentrations of phthalates and bisphenol in a nationally representative sample of the us population aged 6 years and older. PLOS ONE 15,1-21 (2020). URL https://doi.org/10.1371/journal. pone.0236738

[43] Morales, F. J., Mesías, M. \& Delgado-Andrade, C. Association between heat-induced chemical markers and ultra-processed foods: A case study on breakfast cereals. Nutrients 12 (2020). URL https://www.mdpi.com/2072-6643/12/5/1418.

[44] Ibsen, D. B. et al. Food substitution models for nutritional epidemiology. The American journal of clinical nutrition 113, 294-303 (2021).

[45] Adams, J., Hofman, K., Moubarac, J. C. \& Thow, A. M. Public health response to ultraprocessed food and drinks. BMJ (Clinical research ed.) 369, m2391 (2020).

[46] What We Eat In America (WWEIA) Database. URL https://data.nal.usda.gov/ dataset/what-we-eat-america-wweia-database. 